\title{
Archipel
}

ARCHIPEL Études interdisciplinaires sur le monde insulindien

$97 \mid 2019$

Varia

\section{JAVA : ARTS AND REPRESENTATIONS. Art historical and Archaeometric Analyses of Ancient Jewellery (7-16th C.) : The Prillwitz Collection of Javanese} Gold

Analyses stylistiques et archéométriques de bijoux anciens (VII ${ }^{e} X \mathrm{VI}^{e}$ siècle) : la collection Prillwitz d'or javanais

Mai Lin Tjoa-Bonatz and Nicole Lockhoff

\section{(2) OpenEdition}

\section{Journals}

Electronic version

URL: https://journals.openedition.org/archipel/1018

DOI: 10.4000/archipel.1018

ISSN: 2104-3655

\section{Publisher}

Association Archipel

\section{Printed version}

Date of publication: 11 June 2019

Number of pages: $19-68$

ISBN: 978-2-910513-81-8

ISSN: 0044-8613

\section{Electronic reference}

Mai Lin Tjoa-Bonatz and Nicole Lockhoff, "JAVA : ARTS AND REPRESENTATIONS. Art historical and Archaeometric Analyses of Ancient Jewellery (7-16th C.) : The Prillwitz Collection of Javanese Gold", Archipel [Online], 97 | 2019, Online since 11 June 2019, connection on 15 September 2021. URL: http:// journals.openedition.org/archipel/1018; DOl: https://doi.org/10.4000/archipel.1018 


\title{
JAVA: ARTS AND REPRESENTATIONS
}

\author{
MAI LIN TJOA-BONATZ AND NICOLE LOCKHOFF ${ }^{1}$
}

\section{Art historical and Archaeometric Analyses of Ancient Jewellery (7-16th C.): The Prillwitz Collection of Javanese Gold}

\section{Introduction}

Jewellery has been the most common form of gold ware found in Southeast Asia since the late 1st millennium BCE. Those items included are ear ornaments and rings - worn on the fingers, ears, toes or as pendants. During the 7 th to early 16 th centuries, ${ }^{2}$ conventionally referred to as the Classical Period, Java produced mostly unique rings in a copious variety and intricate

1. Dr. Mai Lin Tjoa-Bonatz is an art historian and archaeologist, tjoabonatz@gmail.com. Nicole Lockhoff is a research associate at the CEZA in Mannheim, Germany, nicole. lockhoff@ceza.de. The research was partly funded by the FAZIT Stiftung and the gender projects of the Goethe Universität, Frankfurt am Main. An earlier version of this article was presented at the international conference of the European Association of Southeast Asian Archaeologists in Posnan, Poland, in July 2017. We are most thankful to Prof. Ernst Pernicka and Prof. John Miksic, who gave valuable guidance. Curators such as Steve Timisela, Edi Irianto, Dr. Achim Sibeth, Vanessa von Gliszczynski, Dr. Stephen Murphy, Dr. William Southworth, Dr. Alex Green, Dr. Georg Noack and Dr. Francine Brinkgreve facilitated access to their collections. Special thanks also go to Dr. Michael Flecker and Dr. Horst Liebner who have provided images of wreck finds. We are indebted to Prof. Adalbert Gail, Dr. Gerd Mevissen, Amita Kini-Singhand Dr. Shivani Kappor for their advice on Indian iconography and coins. We thank Prof. Marijke Klokke, Pauline Lunsingh Scheurleer, Dr. Jutta Engelhard and Dr. Annabel Teh Gallop for assisting us. Prof. Eusebio Dizon and Prof. Jan Wisseman Christie made their unpublished manuscript available to us. The comments of anonymous referees, Dr. Daniel Perret and Dr. Henri Chambert-Loir were of immense help.

2. The dating is CE unless indicated otherwise. 
workmanship indebted to a Hindu-Buddhist iconography. The Weltkulturen Museum in Frankfurt am Main holds the largest corpus of ancient gold and silver jewellery from the Indonesian island of Java in Germany. The collection includes 224 pieces acquired in 1913 from the German ornithologist Conrad Ernst August Prillwitz, in addition to seven pieces from other German collectors. ${ }^{3}$ Apart from a small number of objects which have appeared in an exhibition catalogue and preliminary reports, the gold treasure is relatively unknown (Karow 1987: 293-4; Tjoa-Bonatz 2017 a, b). It is an important reference study collection for various reasons.

Firstly, archaeometric analyses obtained by the Curt-Engelhorn-Centre Archaeometry gGmbH (CEZA) and generously sponsored by the Golden Lotus Foundation Singapore allow one to look in greater depth at the chemical content, technological examinations and surface analyses. A total of 25 objects were examined by non-invasive energy-dispersive $\mathrm{x}$-ray fluorescence spectrometry (ED-XRF). Additionally, the trace elements in two samples were analysed by laser-ablation inductively coupled plasma mass spectrometry (LA-ICP-MS) (Fig. 9, 18). This very sensitive analytical method allows the determination of fingerprints via trace element compositions, which, for instance, can be used to identify workshops (Schorer et al. 2018) or help to reconstruct the manufacturing history of complex objects (Lockhoff and Pernicka 2014). However, neither method can date gold. What the scientific methods can do is define the composition of the raw material and, thereby, contribute information on the manufacturing processes and issues related to authenticity.

Secondly, the value of antique jewellery on the international art market has risen sharply since the $1980 \mathrm{~s} .{ }^{4}$ This has led to the inundation of the market with modern attempts to recreate well-made fakes and reassembled or overrestored objects. Although the exact provenance of the Prillwitz collection is not known, it is important to present an old collection of gold ornaments to which a high degree of reliability as a historical source can be assigned.

Thirdly, art history is still establishing chrono-typological markers for the history of jewellery made of precious materials in Southeast Asia; this article aims to contribute to this discussion by drawing comparisons between styles, motifs and iconography. Some of the goldwork can be compared to examples with a concrete provenance or secure archaeological contexts. Comparative studies,

3. These are a pair of encrusted ear ornaments from Java obtained by the Großherzogliche Privatkabinett Darmstadt in 1919 (inv. no. 23183 a, b), one ear ornament with clip from Johannes Elbert, who pursued an expedition to the Lesser Sundas in 1909-10 (inv. no. 23256), and six earplugs and rings from Yogyakarta, Central Java, from the anthropologist Ernst Vatter (1888-1948), who travelled to Java and the Lesser Sundas in 1928-29 (inv. no. 27429-27435 a, b; Barnes 2004).

4. Compare the prices of gold rings and ear ornaments in auction catalogues: HabsburgFeldman (1990: 82-100), Stark (1992: 150-195), Sternberg (1995: 60-83); Christie's (2005: lots 170-1; 2016: lots 35-45). 
however, have their limitations in the case of unique or unprecedented objects. Craftsmen during the Classical Period were probably following established patterns passed down for generations, and, in most cases, we cannot discern whether and why they were engaging in innovation. Not much is known about the actual work process, artistic practice and interplay between the workmen and parties who commissioned the goldwork. The dating of Javanese goldwork still remains rather problematic, though stylistic characteristics, textual references and workmanship sometimes allow us to distinguish artefacts made during the Early Javanese Period, which flourished in Central Java from the 7th to the early 10th century, from those belonging to the Late Javanese Period, from the 10th to the early 16th century in East Java. Most of the gold artefacts lack provenance about their precise find spots and if a regional origin from West, Central or East Java is given, it is not conclusive for dating. The style is not always congruent to the regional classification. Many archaeological sites have a continuous settlement horizon, some of them even from the Protoclassic (1st-6th century) onwards; other sites are not well-documented, therefore, we have to be cautious about attaching an item to a specific phase.

Based on this complex situation, the problem of dating ancient Javanese gold can only be assessed by relying on a combination of archaeometric material analyses, historical references and stylistic evaluations with comparative examples from old collections, archaeological sites or with other provenanced material.

\section{Reference Collections}

Several exhibitions since 1995 have raised public awareness of the amazingly rich gold treasures in the National Museum in Jakarta, including finger-rings and earrings from archaeological contexts or hoard finds (Groeneveldt and Brandes 1887: 283-94; Eggebrecht and Eggebrecht 1995: 130-2; GirardGeslan 1995; Tokyo National Museum 1997: 158-9; Queensland Art Gallery 1999; Brinkgreve et al. 2010; Lunsingh Scheurleer 2010; National Museum of Indonesia 2013). However, a full reference collection of the gold stored in the Museum Nasional Indonesia is still not yet available. The museum permits no photography and their store-room is not accessible. The museums Sonobudoyo in Yogyakarta, ${ }^{5}$ Mangkunegaran in Solo and Ranggawarsita in Semarang in Central Java, and the Museum Mpu Tantular in Sidoarjo in East Java hold rich collections of gold jewellery (Stutterheim 1937; Griffiths 2012: 489-93).

The most significant gold collections outside Indonesia are those amassed before World War II, such as in the British Museum in London and several museums in the Netherlands. Most of the material is accessible online or through publications of the Museum Volkenkunde Leiden, the National Museum of World

5. In 2010, 87 artefacts including gold plates, jewellery, a mask and statuettes were stolen (Sri Wahyuni 2010). 
Cultures in Rotterdam, the Gemeentemuseum Den Haag, the Tropenmuseum and Rijksmuseum in Amsterdam (Juynboll 1909: 179-85; Dalton 1912: 336-40; Lunsingh Scheurleer 2012; de Bock 2014). There is a small yet to be published pre-war gold collection in the Weltmuseum Vienna, Austria.

Most of the Javanese jewellery collected by individual connoisseurs is of insecure provenance. Some of these private collections amassed in the last quarter of the 20th century were made accessible in museums: in the US, the Hunter Thompson collection at Yale University Art Gallery in New Haven, the Samuel Eilenberg collection in the Metropolitan Museum of Art in New York and one in the Fine Arts Museum of Houston (Miksic 2011a; Marzio 2011: 196-211); in Europe, the Giuseppe Tucci collection in the National Museum of Oriental Art in Rome, Italy, the Jaap Polak collection in the Linden-Museum in Stuttgart, Germany, and the Frits Liefkes collection in the Museum Volkenkunde Leiden (G. K. 1984: 35, fig. on p. 29; Rispoli 2000; Lunsingh Scheurleer 2013; de Bock 2014). The gold collection in the Singapore Asian Civilisations Museum was amassed by different donors (Miksic 1988; Chin 1994). Other private collections of Javanese jewellery are described in publications (Polak 1980; Shirley Day 1992, 1993; Wenzel 1993; Ghysels 2000; Middleton 2005: 130-47; de Bock 2014; Geoffroy-Schneiter and Crick 2016; Golden Lotus Foundation 2018, 2019).

Other important pieces of reference material are the gold jewellery retrieved from sunken ships. Adornment with precious materials was carried by affluent individuals among their personal possessions and was also part of the commodity trade on international shipping circuits according to Horst Liebner (2014: 184, 188). Ships travelling between Sumatra and Java carried not only goods worked in gold, but also goldsmithing implements, ingots or other raw material. The gold on the Intan wreck of the late 10th century found in the Java Sea included 40 gold rings (Flecker 2002: 73-4, 77; Ekowati Sundari 2009: 104, fig. 7.7). The Cirebon wreck of the 10th century found north of Java yielded a rich collection of more than 500 pieces of jewellery, scrap material for goldsmiths, in addition to gemstones and intaglios, some of which are comparable to similar pieces from the Western Indian Ocean regions, China and Java (Liebner 2014: 182-91, fig. 2.3-39-41, 2.3-43, 2.3-51; Guy 2011: fig. 3.2.4).

We will focus on objects with a secure provenance, mainly from pre-war collections and excavations, as reference material and for dating. However, it is not always possible to date gold artefacts unambiguously to a specific phase.

\section{The Collector Conrad Ernst August Prillwitz}

Most of the 224 gold objects in the Frankfurt Weltkulturen Museum were acquired by the ornithologist ${ }^{6}$ Conrad Ernst August Prillwitz, a German who

$\overline{\text { 6. Three eponyms }}$ of birds carry Prillwitz's name. 
was born near Cologne in Heimersheim/Ahr on the 16 November 1856. In 1897, he moved to Java where he lived until his death on the 7 September 1943 in Malang, East Java. Between 1903-6 he stayed in Germany. After his first marriage to Johanna Hüpen in 1906 or 1907 who passed away in Germany in the same year, he married M. M. J. A. Houweling, who originally came from Malang. Prillwitz had three sons and one or two daughters. Between 1898 and 1901, he undertook extensive travels through Java, Madura and Malaysia (Puteran?). ${ }^{7}$ From West Java, where two of his sons - Ernst Adelbert Johann in Sukabumi in 1898 and Peter Maximilian Hermann in Garut in 1910 - were born, he moved to Malang in East Java, where at least two more children - Adelbert Hendrik Johann in 1906 or 1907 and Margaretha (Magda and/ or Maria Magdalena?) in 1918 - were born. ${ }^{8}$ His first sons obtained Dutch citizenship in 1922 and subsequently lived in the Netherlands, whereas the third one died as a sergeant in the Royal Netherlands East Indies Army in camp Matona in Thailand in 1943 during World War II.

The reasons Prillwitz started collecting gold jewellery and why he sold artefacts to museums is not known. In 1903, his collection comprised 550 artefacts, with a strong interest in ancient arts mainly from Java but also from Lombok, Borneo or Sumatra, such as Chinese porcelain, stone adzes, textiles, bronzes, stone sculpture and "Majapahit krisses" from the Majapahit period (1293-c. 1527). ${ }^{9}$ Prillwitz was in touch with various ethnological museums. Apart from 11 pieces of gold jewellery, he offered Hindu-Javanese antiquities for sale to the ethnographic Museum in Berlin. According to the museum's curator, these items far exceeded those in Dutch museums in quality, although Prillwitz still held back the best pieces. In 1906, the museum obtained 130 objects, mainly from Java. Some were bought directly from Prillwitz in addition to others which were donated by the art dealer Theodor Glucksmann. ${ }^{10}$ In 1913, Prillwitz sold 665 items to the ethnological museum in Frankfurt from the Indonesian islands of Bali, Sumatra, Borneo, Timor, Flores, Madura, Belitung,

7. His travels are documented in four letters of 1901 which were sent from Sukabumi, Jakarta (formerly Batavia), Garut in West Java, today's regency of Purworejo (Gambang?) in Central Java and Malang in West Java (Natural History Museum in London, ref. no. TM/1/58/14, TM/1/156/18).

8. Historisch Genootschap Valkenswaard: http://www.shgv.nl/Naturalisaties\%20pet-spe.htm; http://naturalisaties.decalonne.nl/indexddb.php?table_name=naturalisaties\&function=search \&where clause $=\&$ order $=$ graftombe\&order type=ASC $\&$ page=223; Stamboomsucher: http:// www.online-familieberichtennl/zoeken.asp? command $=$ show\&id $=665255$; a photo of his wife and son, Ernst Adelbert Hendrik, was taken in 1908 in Malang: http://media-kitlv.library.leiden. edu/image/5f93cdf8-b55f-ed46-62df-7c77df394b46 (consulted 12.2.2018).

9. Records in I/MV 425 EIB63 Asien (Archive of the Staatliche Museen Preussischer Kulturbesitz); Roland Platz, personal communication 1.8.2018.

10. Among them, 100 items are associated with Johann Hüpen, his father-in-law. After the donation in 1907, Glucksmann was awarded a medal of the fourth grade. 
Sulawesi and Java: gold jewellery, 112 weapons, 33 musical instruments (including bells), 85 textiles and eight masks. In 1919/20, he offered Javanese artefacts to the museum in Cologne. ${ }^{11}$ In 1940, for political reasons, the Prillwitz collection, probably the one in Frankfurt, was devalued by stating that the rings and other gold jewellery contained very few pieces that could not be found in one or more public collections in the Netherlands (Anonymous 1941: 5). ${ }^{12}$ Because of the war between Germany and the Netherlands, Germans such as Prillwitz in the Dutch East Indies, were considered "undesirable". One of the collector's most elaborate pieces of gold jewellery was kept in his family long after his death. In memory of her father, his daughter Margaretha, who married M. Seth in February 1942 in Surabaya, bequeathed an ear plug from Malang to the Victoria and Albert Museum in London (inv. no. IS.13-2003).

Vanessa von Gliszczynski ${ }^{13}$ argues that his selection of objects complied with the demands of the European market and he could finance his research trips by selling them. If we, thus, assume that he collected artefacts only for material profit, this ignores his broad connoisseurship, networking talents and broad interest in the material culture of the Indonesian archipelago including different crafts and functions - from weapons to utensils, from shadow puppets to painted glass, from adornment to ritual objects - underpinned his deep appreciation of the arts and material culture, including both antiquities and ethnographica.

Most of Prillwitz's gold objects in the Frankfurt Weltkulturen Museum, apart from 60 pieces only broadly ascribed as being from Java, are said to have come from his hometown, Malang. However, not all might have originated from East Java or the Late Javanese Period, as his frequent travels and moves suggest and the stylistic evaluation below will show. Although his jewellery collection lacks precise provenance information, it serves as an important and old reference collection.

\section{Socio-Cultural Functions of Gold Rings and Ear Ornaments}

Gold rings and ear decorations were worn by both genders during the Classical Period. As seen on statuary, rings were worn around the neck as pendants. The fingers and toes of deities and the nobility were fitted with rings. The practice of wearing the ring on the lowest joints of the fingers on both hands was common. Rings are often paired: worn on both thumbs, on the small and big toes, or a thumb-ring together with another one on the little finger. The middle finger appears to be avoided when more than two rings are worn (Golden Lotus Foundation 2018: fig. on page 25). Rings fulfilled various functions.

11. Historical Archive of Cologne, 1907-21, file 557.

12. We would like to thank Pauline Lunsingh Scheurleer for bringing this reference to our attention.

13. Personal communication 29.5.2018. 
Firstly, rings were a part of burial customs. Pre-Islamic high-status burials in Sulawesi between 1300 and 1600 contained a variety of gold ornaments, including Javanese-style rings (Bougas 2007: 112, 128). In religious contexts, rings of precious material and other jewellery were found as ritual objects at temples or royal hermitages in 9/10th century Java at the Seplawan cave, Candi Ijo and Wonoboyo (Wahyono Martowikrido 1994; Lunsingh Scheurleer 2010: 30-1; Miksic 2011a: 62, 64-6). Rings were buried underneath the temple foundations of the 14th century Sintong temple in Riau, Sumatra (Eka Asih Putrina Taim 2017).

Secondly, rings were items of transaction and commerce. A relief on the Borobudur temple depicts a gold shop where rings were sold with other products of the goldsmith (Miksic 1990: fig. on p. 36). Another relief shows coins and rings as items in a transaction and jars for storing the valuables (Golden Lotus Foundation 2018: 26). These valuable materials, particularly gold coins, formed a currency standard in themselves. Gold was used to pay fines, salaries or courier services (Robson 1971: 105; Miksic 2011a: 27-31). It functioned as a standardised payment, but gold rings "formed a class of special-purpose money" and were, thus, part of rather specific transactions (Christie 1993). Rings, amulets, garments and other jewellery were exchanged as love tokens in literary sources of the 12-16th century (Robson 1971: 226; Creese 2004: 109). Gold rings were a part of wedding presents and gift exchanges, but they did not appear as a part of a purchase or tax payment (Robson 1971: 167; Christie 1993, 2015). During the late 9th and early 10th century, gold rings are mentioned in gift lists, regarding privileged territorial units (sima) grants in Central and East Java. These gold rings are called simsim pasāda/prasāda in Old Javanese. The first term means "ring" and the second, borrowed from Pali, can be translated as "purity, faith, luck, propitiatory gift". ${ }^{14}$ Jan Wisseman Christie (1993) has compiled 11 inscriptions in Old Javanese and Old Balinese between 824 and 943 in which the recipients of these rings or textiles were mostly individuals, men and women alike. Rings were also presented among the gifts to the local founding ancestor or a Brahma shrine. Gift-giving reached a peak during the 870s/880s: A Central Javanese charter of 882 even includes a total of 53 rings (Christie 1993). Other references on five Balinese copper inscriptions written in both Old Balinese and Old Javanese from 922-1072 describe this ring type as "Singhalese-style rings" and one "with the royal seal" which probably means motifs connected to South India (Christie 1993; 2015; Gallop 2016: 86-8). It was, thus, assumed that this kind of propitiatory gift ring had a flat bezel rather than a stone bearing an auspicious symbol or inscription. Our style and chemical analyses will give more insights which substantiate this assumption.

14. Following Christie (2015: 80), different to Barrett-Jones' (1984: 34) interpretation of prasada woh, who suggested that a temple is on these rings. 
When pretty and talented maidens attained the rank of kawi, which means being accomplished in literary techniques, dancing, music and other sorts of artistic activity, they had a ring called a karah bestowed on them. According to the East Javanese courtly poem Sumanasāntaka of the 13th century, twenty of these maidens were counted in the retinue of a princess (Zoetmulder 1974: 160). Other female gamelan players who could sing and recite had bracelets presented to them. Those with more advanced skills were rewarded with a necklace and an ornament for their clothing. A dress of golden and jewelled scales was the highest accomplishment presented to court artists (Zoetmulder 1974: 159-60). Apart from a graduated system of certain types of jewellery, the degree of proficiency in the performing arts was also rewarded according to the weight of the gold items.

Thirdly, beyond these mundane functions, rings were believed to carry good fortune, to provide protection to the wearer or to change fate (Bosch 1927: 313; Machi Suhadi 1999; Richter 2010: 167-8; Miksic 2011a: 25; Gallop 2016: 132, ft. 16, 146). People believed in the amulet function of gold, which is said to contain a higher concentration of potency than other nonanimated objects (Westerkamp 1995; Bougas 2007: 141). Certain animals or colours of stones in rings were associated with specific deities of the HinduBuddhist pantheon, sayings or the zodiac (Friederich 1856: 479, 482-3; Maas 1924: fig. 7, 78; Miksic 2011a: 130-1).

Fourthly, jewellery symbolized the power of the mighty and jewellery was thus ubiquitous and essential to court life (Jessup 1990; Levin 2003, 2005). Golden earrings are mentioned in the epic poem the Ramayana Kakawin, c. $9^{\text {th }}$ century, as insignia of the queens and fruits of richness (Soewito Santoso 1980, I: 73: III, 24; 260: IX, 43). Gold is described as a trophy and war booty, along with "excellent jewels" and women (Soewito Santoso 1980, I: 276: X, 14). Its use was, thus, restricted by sumptuary regulations in the Late Classical Period. In the 12th century, a law decreed that those who fell into debt were excluded from receiving gifts of jewels from royalty (Creese 2004: 57). According to another restriction of 1312, only holders of freehold land were allowed to wear anklets, various kinds of gems and bracelets of gold. Deities and aristocrats were richly attired over the whole body, whereas courtly servants wore less adornment but, at least, earrings and bracelets, in contrast to commoners who wore none or only the simplest forms of jewellery, as seen on the Panataran temple in East Java of the 14-15th century (Kieven 2013: 54).

The full set of personal adornments for the nobility consisted of eight different types of gold items, including earrings, finger-rings, in addition to anklets, armlets, Brahmin's sacred cords, a crest jewel and a diadem, as depicted on the Prambanan of the 9th century and recorded in the Ramayana Kakawin (Soewito Santoso 1980, I: 260: IX: 43). This standard wardrobe repertoire of a noble became much more elaborate; specific terms with certain 
forms and functions were standardised. The Panji story Kidung Wangbang Wideya described 14th century rings, most encrusted with different kinds of stones, which were addressed by various terms and, thus, represented different types: ali-ali, murit or simsim (Robson 1971: 105, 167, 169, 175, 227, 235; 1981: 106, 112). Royal accessories for court life also included a dagger (keris), upper armbands (gěgělang), a bracelet of thread (tětěbus) and bangles (pinggĕl) set with precious stones of the kana or lulut type (Robson 1971:223, $227,237 ; 1981: 106,112)$. A member of the royal family wore his crown, a collar or breast-plate (padaka), a girdle (?, karambalangan) and used gilded armour even in battle (Soewito Santoso 1980, II: 548: XXI, 203; 559: XXI, 241; 569: XXII, 45; Robson 1981: 112).

The story of Arjuna is told on the walls of Surowono, an East Javanese temple of around 1400. He personifies the ideal Javanese king: noble demeanour, victorious and brave. Before his temptation by beautiful nymphs, they prepare themselves to meet him (Kinney 2003: fig. 215). Richly bejewelled with bracelets, many sashes, anklets and round earrings, one adjusts her coiffure, while another looks at herself in a mirror. This visual manifestation of power evolved out of high aesthetic ideals and was materialized in the ostentatious pursuit of beauty. Not only did the elegant jewellery add to a female's charm and exult in her beauty, as described in the 13th century, women themselves, particularly maidens of aristocratic birth, were regarded as prized jewels (Creese 2004: 148, 156). They were like a precious jewel displayed then hidden away until a great prince comes and breaks open the jewel of a young maiden on the bridal couch. These metaphors dealing with jewellery, though encompassing patriarchal and male sexist perspectives, express an extensive cult of beauty connected to gold (Creese 2004: 46, 68).

The head was the prime focus of lavish personal adornment in the Kidung Wangbang Wideya. Apart from a metal headband (bělěngker), sometimes a diadem (tutup gĕlung) and most often ornaments (sěkar) of gold which featured different flower shapes and forms, such as a jasmine branch or various unknown species with leaves of green glass ornaments, were inserted in the hair ${ }^{15}$ Three ear ornaments are distinguished in classical texts, of which the first two can be assigned to artefacts in the Prillwitz collection: eardrops (anting-anting), some of which show a kalacakra design, a combination of a kala head and a discus (cakra); ear-studs (suwěng or pěpělik); and ornaments set behind the ear (sumpang), some of which are in the shape of a "moonorchid" (Robson 1971: 97, 235; 1981: 106, 112). Ear ornaments were thus worn at different places: behind the ear, inside the pierced lobe, hooked

15. Robson (1981: 106, 112); Unknown rabayut, prabusatmata or parijata flower or shapes such as pupulutan, sĕsĕmen kinitir-kitir or pupu were distinguished (Robson 1971: 149, 167, 169, 197, 227, 233). 
through the lobe. ${ }^{16}$ Pierced lobes were elongated to such an extent that they nearly reached the shoulders. Several clips were set above each other on both sides of the elongated earlobes (Golden Lotus 2019: fig. on p. 95).

Addressing jewellery types with the wording in historic texts will be henceforth applied. Sumpang might consist of an elongated leaf of gold foil. ${ }^{17}$ The eardrops might be associated with pendant " $u$ "-shaped ear ornaments which were hooked through the pierced earlobes and show a decoration on both sides, sometimes figurative images, for example, the kala head. Earstuds feature circular or discal ear-plugs and were meant to hug the inside of the lobe. They consist of up to six parts fitted one into the other forming an open-work box. ${ }^{18}$ Open-worked circular boxes, such as the pair of ear-studs which formerly belonged to the Prillwitz collection, may have been filled with aromatics (Victoria and Albert Museum inv. no. IS.13-2003). R. Goris (1927: 111) coined them "tamarind pod earrings" and assumed that they symbolized "clear sight with apparent stupidity", such as those seen on a Bhima statue from fifteenth-century Candi Sukuh in Central Java. John Guy (2008) called them kundang-subang and proposes that discal ear ornaments have had an unbroken tradition both in India and Indonesia since the first millennium. In Classical Java, they were worn by young men, guardians, warrior, ${ }^{19}$ Bodhisattva, female deities, seducing women or were presented as a royal gift to a princess, and their motifs refer to planetary concepts, status and protection (Robson 1971: 175; Lunsingh Scheurleer 2012: ill. 38).

Apart from drawing comparisons of style and motifs seen on stone statuary and reliefs, the study of archaeological contexts and written sources from Classical Java widens our understanding of the use, function and typological varieties of gold jewellery as further explored in the following catalogue. Ear adornments are paired, however, different ornaments in either ear were also common. ${ }^{20}$ More single ear ornaments have survived the centuries and, therefore, the pairs found in the Prillwitz collection are rare exceptions.

16. So far, I have not yet found clear evidence on stone statuary with ornaments hooked through the pierced helix.

17. Brinkgreve et al. (2010: 78); see for example a Borobudur relief (Golden Lotus 2019: fig. on p. 47).

18. Most elaborate examples (de Bock 2014: 210-3; Golden Lotus Foundation 2018: 40) cf. Museum Volkenkunde Leiden inv. no. 1403-2605.

19. See a Borobudur relief (Golden Lotus 2019: fig. on p. 17).

20. See a Borobudur relief (Golden Lotus 2018: fig. on p. 95). 


\section{Catalogue of Rings and Ear Ornaments}

\section{Ripped Rings}

The collection holds two split rings that consists of 15 , respectively 18 , discs of double conical profile creating a ribbed outline (Fig. 1a; Frankfurt Weltkulturen Museum inv. no. 19700). The rings are either cast in one piece or the single discs are fused. ${ }^{21}$ Possible joining techniques would have been soldering or welding. ${ }^{22}$ Both metallic solder and reaction solder were already known in classical Javanese gold metallurgy, whether brazing was already common is not certain. They were probably worn as earrings but not as nose rings as suggested by the Leiden Museum's online catalogue.

Split rings with a ribbed outline are similar in design and are among the earliest ear ornaments in Southeast Asia excavated in Cambodia and Vietnam from 500 BCE-600 (Reinecke and Ngyuyen Thi Thanh Luyen 2009: 62-3, fig. 12, 66: fig. 20; Reinecke 2015: fig. 4.14.1-4) and Tanjung Rawa, Western Malaysia, from 200 BCE-1000 (Evans 1932: pl. 36, 1 and 4; Shuhaimi 1991; Ramli et al. 2016). The overview of ribbed rings of Southeast Asia given by Michèle H. S. Demandt (2015: fig. 3) includes a ring from Oc Eo, South Vietnam, from the 1st-7th century. However, it consists of gold beads and, thus, represents another manufacturing technique (Malleret 1962: pl. XXII, no. 829). Strikingly similar in design to the latter are split rings from Java which consist of soldered granules (Frankfurt Weltkulturen Museum inv. no. 19696, Semarang Museum inv. no. 0.4.1041). The latter originate from Wonoboyo Jogonalan Klaten. Similar design effects are created by using various manufacturing techniques: firstly, a tube of a sheet metal is covered with a coiled flattened wire at the Thai site of U Thong, dated to the 3rd-7th century; secondly, the so-called caterpillar-shaped ear ornaments from SamarLeyte, the Philippines, though not securely provenanced, are ribbed tubes of sheet gold (Villegas 2004: 108-9; Bennett 2017: 123, fig. 3.138). Jewellery of

21. Proof of soldering with non-destructive methods, such as ED-XRF, is often not easy, especially if the gold surface has been pickled subsequently. No hint for solder has been found in the case of Fig. 1b. If stained, it is not possible to detect the soldering points either analytically or with a microscope other than in a destructive way.

22. Different bonding techniques, such as sintering, soldering, welding or brazing, are characterised by their working temperature and the materials they need. Sintering is a solid phase bonding technique that requires metal powder and comparatively low temperatures: heating up the powder sticks the grains together. The process ends before the metal becomes liquid. Soldering requires another material, usually a metal, which has a lower melting point than the parts to be joined. A further distinction is made between reaction solder (e.g. copper carbonates), hard solder (typically gold-silver-copper alloys) and soft solder (tin and lead-alloys). Welding is a hot temperature process that is based on carefully heating up the parts that should be joined to liquidus temperature. 
ribbed design is seen on old Javanese statuary and stone reliefs, for example, worn by epic heroes such as Krishna, young men on the Prambanan temple or a stone statue from Blitar, East Java, dating from the Majapahit period (Miksic and Soekatno 1995: 137, no. 26). We have, thus, to be cautious comparing objects of apparent similar but differently executed design.

John Miksic dates split rings of ribbed design from Java to the 4-7th century, whereas some museum curators suggest the Early Classical Period. ${ }^{23}$ This kind of earring is documented from West and Central Java: one from a pesantren (Coranic school) in the village of Kendal, Central Java (Malleret 1962: pl. 20) and two from Cirebon, West Java (Museum Volkenkunde Leiden inv. no. 1745-4, 1745-5). Others are embellished with granulation or use partly ribbed discs, such as an example from Batang, Central Java. ${ }^{24}$ Split rings of fused discs in Java could date to the 1st millennium supported by the provenanced objects.

\section{Wire-wrapped Rings ${ }^{25}$}

The collection includes four different types of rings wrapped around one or several core wires by another wire (Fig. 2-8). Cast examples, by contrast, are later copies or an unrecorded technique from ancient times (Bennett 2015: 222, fig. 6.37). On account of residues of baked clay on wire-wrapped rings obtained in the 1980s, Fiorella Rispoli (2000: 42-3, pl. 1) assumes that the inner core was covered by a thin layer of clay on which the outer wire was wound so that both were set apart. The gaps between the wires of the examples in the Frankfurt Weltkulturen Museum are often less than $0.25 \mathrm{~mm}$ or do not exist, which questions whether this technique was employed in earlier times.

The most common type uses three winding techniques - spiralling, bending and knotting - which allow highly decorative variation. The ring with wires wound up to two-thirds of the hoop is organised in symmetrically arranged sections of six wraps. This puts a special focus on the central part of the ring where it reaches its largest diameter (Fig. 4), which offers close parallels in style to a ring from Lamongan, East Java (Museum Volkenkunde Leiden

23. Miksic (1988: fig. 55; 2011a: pl. 17: inv. no. 2007.142.132, 2007.142.134, 2007.142.135) versus NMW Tropenmuseum (inv. no. TM-2960-302) and the Metropolitan Museum (inv. no. 1998.544.103 a, b); All these examples lack a secure provenance.

24. Museum Volkenkunde Leiden inv. no. 1403-3313; cf. without provenance: Miksic (2011a: pl. 17: inv. no. 2007.142.143, 2007.142.136).

25. This kind of ring received its name from its manufacturing technique and has been variously referred to as a "wire-wrapped ring" (Miksic 2011a: 117), "wound wire ring" (Lunsingh Scheurleer 2012: 97) or "rope-twisted ring" (Bennett 2015: 228, fig. 6.36). The latter is a misleading expression because, unlike a rope, the wire is not always twisted. 


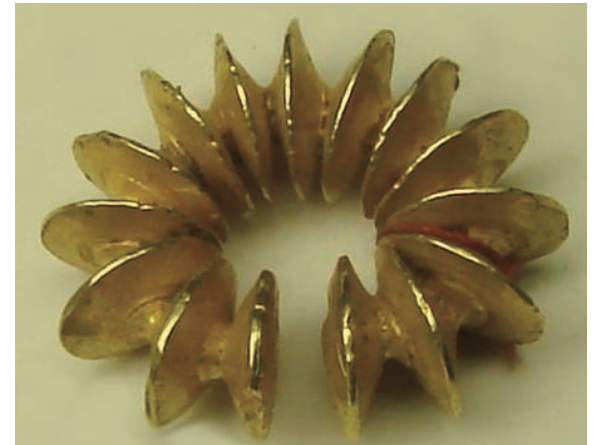

a

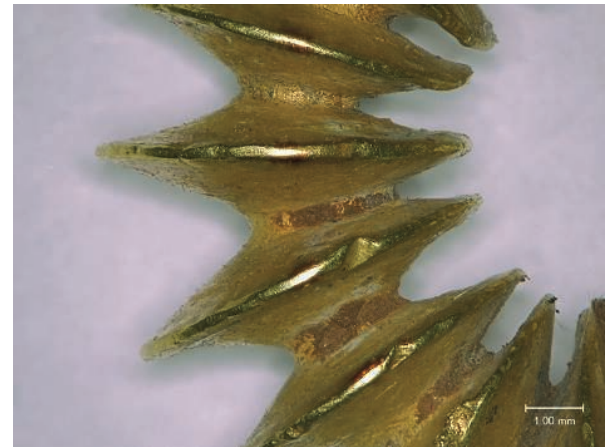

b

Fig 1 a-b - Frankfurt Weltkulturen Museum, inv. no. 19699. Disc-shaped ring, Java, 200-600 with detail (CEZA).

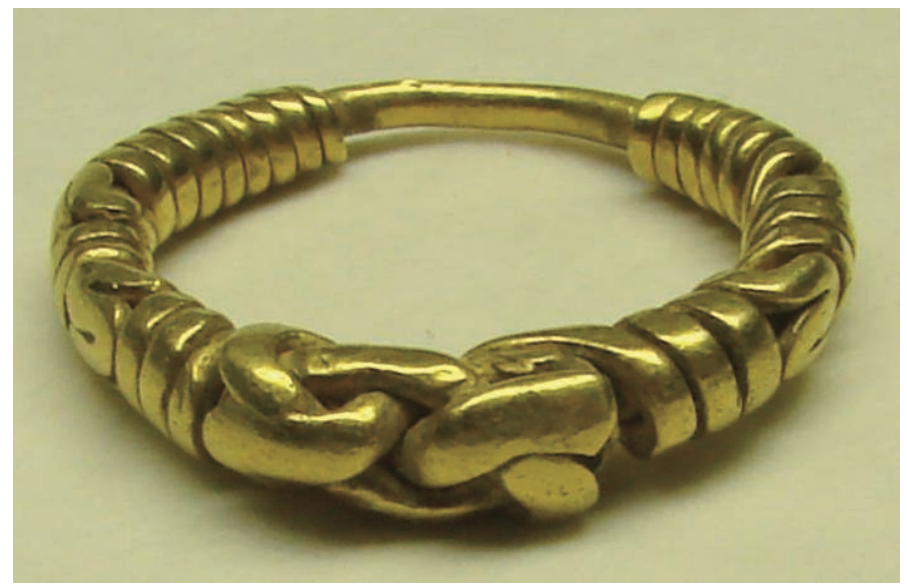

Fig. 2 - Frankfurt Weltkulturen Museum, inv. no. 19742. Wire-wrapped ring, Java, 7 th to early 16 th century.

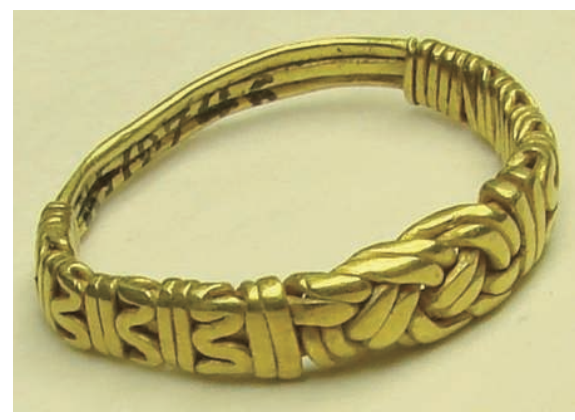

a

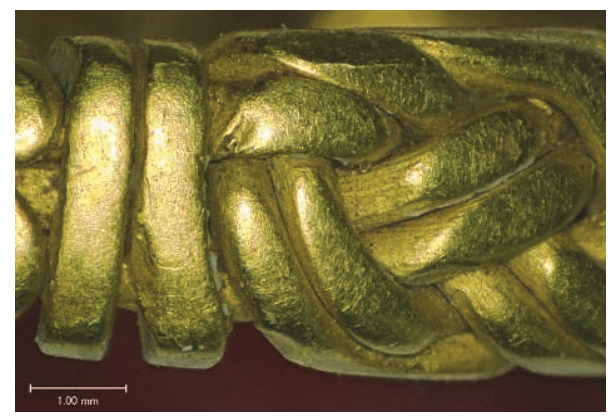

b

Fig. 3 a-b - Frankfurt Weltkulturen Museum, inv. no. 19746. Wire-wrapped ring, Java, 11th to early 16th century; the detail shows striations which run longitudinally along the surface (CEZA). 
inv. no. 1403-3298). ${ }^{26}$ Most rings of this kind have a round diameter, apart from some peach-shaped exceptions, one of which was found in the village Karangbendo/Tege in the district Tekung of the regency Lumajang, East Java (Museum Mpu Tantular Sidoarjo inv. no. 04.136E; NMW Tropenmuseum inv. no. TM-2960-271). They were probably worn as finger-rings and the split ones as earrings, often made as a set. However, the heavy ring of $25.94 \mathrm{~g}$ with a diameter of $2.5 \mathrm{~cm}$ is so large that it might have been used as a toe ring or a pendant (Fig. 4).

Anne Richter (2010: 179) assumes that sacred rings from India woven from organic material served as the prototypes of this kind of ring. This decoration technique used for a gold ring is documented in an archaeological context in Southwestern Asia at Sirkap/Taxila, Northern Pakistan, dated to the 5th BCE-2nd century (Marshall 1975: pl. 191, no. 31-45, 195, no. 105-15, 147). Wire-wrapped rings are found in archaeological contexts in Oc Eo and Khao Sam Kaeo in Southern Thailand, dated to 400-200 BCE, using hammered and folded wire (Malleret 1962: pl. XXII; Bennett 2017: fig. 2.51). A Pyu ring from Myanmar of the 2nd/3rd-9th century is wire-wrapped but lacks any provenance (Tan 2015: 160).

The three wire techniques have been applied since protohistoric times in Indonesia, shown by an open silver bracelet from Bedayu, Lumajang regency in East Java, dated to 200-600, a gold bracelet from Batujaya Segaran IIA in West Java and a gold finger ring from Air Sugihan, Southeast Sumatra, dated to the 4-13th century (Djafar 2010: fig. 3.64; National Museum of Indonesia 2013: 114; Agustijanto Indradjaja et al. 2015: fig. 34). Most scholars ${ }^{27}$ have assigned this kind of ring to the protohistoric period and only a few others to the Central Javanese Period. ${ }^{28}$ However, the occurrence of wire-wrapped rings in both regions, Central and East Java ${ }^{29}$ implies that this technique was ensured longevity during the entire Classical Period (Lunsingh Scheurleer 2012: 1013). Complex wire techniques such as multi-layered cores (Fig. 3a-4), twisted wire or wire with square sections seem characteristic during the Late Classical

26. Cf. nearly identical ones are in the Frankfurt Weltkulturen Museum inv. no. 19740, 19741 and the NMW Tropenmuseum inv. no. TM-2960-270, TM-2960-257, however, all without provenance.

27. Rispoli (2000: 68); Miksic (2011a: pl. 13); Lunsingh Scheurleer (2012: 97-9); Bennett (2015: 222). Cf. a small ring displayed in the Rijksmuseum is dated to the 2nd-8th centuries. However, all are without provenance.

28. Metropolitan Museum inv. no. 1998.544.374, 1998.544.376, 1998.544.380, 2001.794.153; Habsburg-Feldman (1990: 88-9). They are all without any provenance.

29. Cf. from Central Java (Stutterheim 1937: fig. 38, 40: C431-3); from the regency Lumajang, East Java: the village Karangbendo/Tege in the district Tekung (Museum Mpu Tantular inv. no. 04.140 E, 04.123-04.126E, 04.129E, 04.132E, 04.133E, 04.134E, 04.137E, 04.139E) and the district Suwito Yosowilangun (Museum Mpu Tantular inv. no. 04.322E). 
Period. East Javanese stone statuary of the 14-15th century is adorned with torques and necklaces of wire decoration. ${ }^{30}$

Examining the examples in the Frankfurt Weltkulturen Museum under the microscope allows a closer look at the manufacturing technique: the ring with a single core consists most likely of a hammered and folded cast wire (Fig. 2). Parallel but intersected striations which run longitudinally along the surface of the wire in the lower part of Fig. 3 b are evident under the microscope and could result from polishing the raw wire with a cloth or leather and not necessarily from drawing the wire. It is, thus, not possible to decide if it is a drawn or hammered wire. Drawn wires were not widespread until the end of the $1^{\text {st }}$ millennium and their increased popularity in Southeast Asia was influenced by the trade with either the Islamic world or China (Bennett 2017: 67). Drawn wire was identified in Kota Cina dating from the 12-14th century (Swan and Scott 1986). Their triangular cross-section could have been produced by stripdrawing, i.e. a strip rather than a cone was drawn through holes, which is physically much easier.

The second wire-wrapped ring type in the Frankfurt Museum features an earring made from a finely braided wire consisting of twisted wire and square finials decorated with triangular leaf shapes (Fig. 5). This kind of braided filigree is recorded on a piece from the Intan wreck, though represented by an unfinished and distorted ring without finials (Flecker 2002: 74, fig. 5.101). Parallels are seen in the following pieces which are of unsecured context: a finely braided split ring roughly assigned to the pre-1521 Philippines and the shape of the finials of a braided split ring (Stutterheim 1937: fig. 41: C-525; Villareal 1995: 12, fig. 15). The piece from the Frankfurt museum can probably be assigned to the Central Javanese Period.

The third and most sophisticated example in this subgroup features split and encrusted rings. The core wire is fully wrapped by a plain or twisted wire (Fig. 6-7; Frankfurt Weltkulturen Museum inv. no. 19684). The stone is placed opposite the opening and is flanked by granulation or a wire. The stones clasped by thin claws are enclosed in a bezel cup with an indented rim which is either plain or with floral decoration on the outside. The hoop's ends are simply cut (Fig. 6) or clasped by a platelet of flat or convex shape (Fig. 7). Although different dates are proposed, ${ }^{31}$ Lunsingh Scheurleer (2012: 100-1) suggests a dating to the Majapahit period of the second half of the

30. Lunsingh Scheurleer (2012: 115); National Museum of Indonesia (2013: 23-4). By contrast, Richter (2010: 186, fig. 182) has dated the collar to the 16th century.

31. Habsburg-Feldman (1990: 88, no. 129) assigns a similar ring to the 10th century. Two rings of this kind (Metropolitan Museum inv. no. 1998.544.355, 1998.544.350) are dated to the second half of the 8/10th century, whereas Shirley Day (1992: no. 28) proposes a wider dating span of the 6-12th centuries; cf. Stutterheim (1937: fig. 38, 40: C 438). However, all these rings have no firm provenance. 


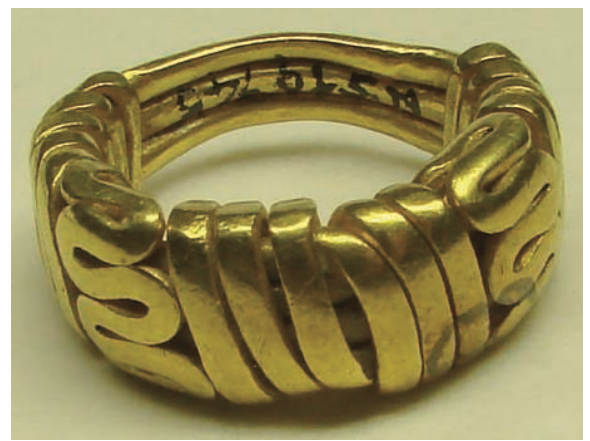

Fig. 4 - Frankfurt Weltkulturen Museum, inv. no. 19744. Wire-wrapped ring, Java, 11th to early 16th centuries.
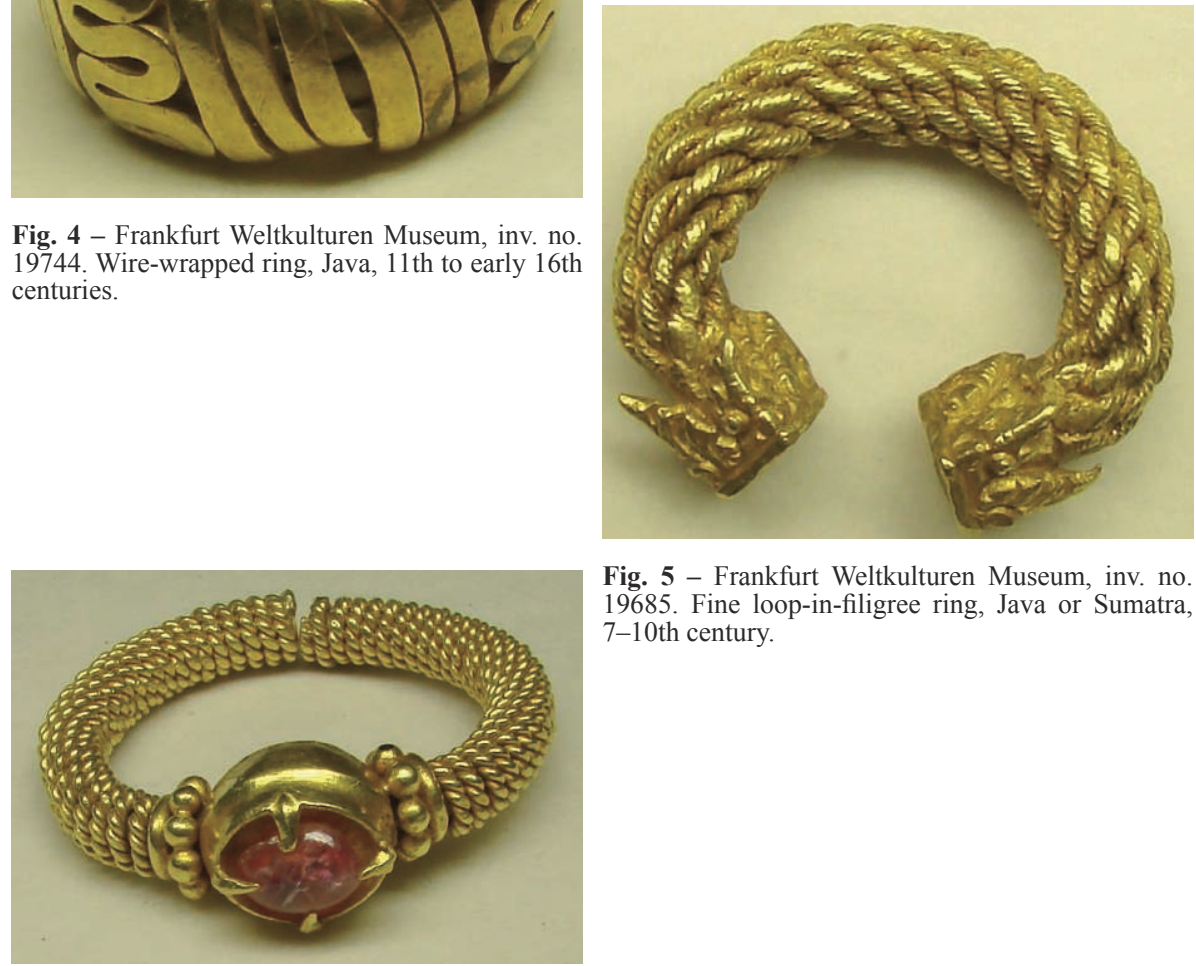

Fig. 5 - Frankfurt Weltkulturen Museum, inv. no. 19685. Fine loop-in-filigree ring, Java or Sumatra, $7-10$ th century.

Fig. 6 - Frankfurt Weltkulturen Museum, inv. no. 19682. Wire-wrapped ring encrusted with a stone, Java, 11th to early 16 th century.

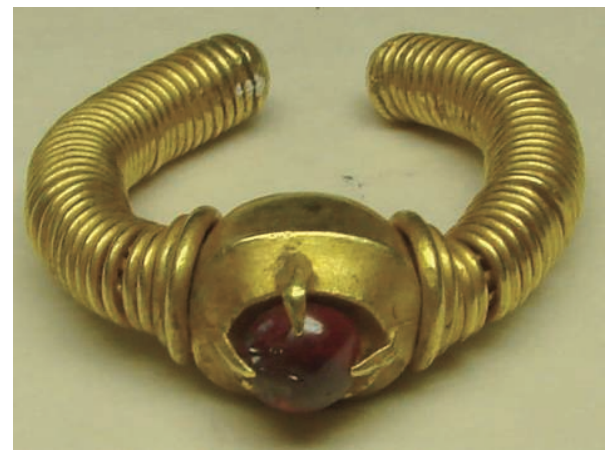

Fig. 7 - Frankfurt Weltkulturen Museum, inv. no. 19683. Wire-wrapped ring encrusted with a stone, Java, 11th to early 16 th century. 
14th century, but she is not sure how it was worn. Seven examples of this type mostly found in the villages Duwet/Pucanganom, Wagiran in the regency Kediri, now stored in the Mpu Tantular Museum (inv. no. 4.345E, 4.87E, $4.89 \mathrm{E}, 4.90 \mathrm{E}, 4.91 \mathrm{E}, 4.92 \mathrm{E}, 4.93 \mathrm{E}$ ), are sound proof that this encrusted split wire- and filigree-wrapped ring, probably worn as earring, is typical of the late Classical Period.

The fourth ring type in the Frankfurt Museum in this subgroup is also split, wire-wrapped or filigree-wrapped but smaller and with the ends of the core wire bent-over (Fig. 8a-b; Frankfurt Weltkulturen Museum inv. no. 19687, 19686 a, b, $19691 \mathrm{a}, \mathrm{b})$. $^{32}$ It holds either a gemstone bezel in an oblong setting or golden beads. If set asymmetrically on the hoop, the use as an earring is indicated (Frankfurt Weltkulturen Museum inv. no. 19688, 19689 a, b). Miksic assigns this type of ring of which two originate from Malang to the Protoclassical Period. ${ }^{33}$ Although East Java is not devoid of prehistoric sites, the numerous examples stored in the Museum Mpu Tantular and found in various East Javanese districts could likewise suggest a dating to the Late Classical Period. The find spots of the Mpu Tantular's collection are the following: Malang; the village Rambakan/ Suroso, district Besuki in the regency Probolinggo; the village Bulangan/Dukun, district Gresik; the village Joko/Karni, district Semen; the village Duwet/ Pucang Anom, district Wates in the regency Kediri; and the village Geger/ Yono, district Sendang in the regency Tulungagung (inv. no. 04.314E, 04.317E, 04.46E, 04.77E, 04.81E, 04.82E, 04.87E, 04.91E, 04.96E). It is not known if this ring belongs to the Protoclassic or East Javanese Period; however, due to the frequent occurrence in East Java, it would represent a simpler and smaller version than the contemporaneous but more prestigious model of Fig. 6-7.

\section{Horn-shaped Ring}

Horn-shaped rings are characterised by a stirrup-shaped hoop with bulbous, elevated shoulders reflecting the form of water buffalo horns, a widespread symbol in Southeast Asia. Parallel bands further accentuate the "u"-shape of the shank. The designation " $u$ "-shaped hoop of planoconvex profile which widens to broad shoulders was coined by Miksic (2011a: 157) as a stirrup form. The ornamental ones include tendrils,${ }^{34}$ seen on Fig. 9, four-petalled flowers, hatches or notches. The heavy cast ring shows the Sri letter in Old Javanese script on a barrel-shaped bezel. ${ }^{35}$ It consists of an arched "ś" above

32. Cf. Museum Volkenkunde Leiden inv. no. 1403-3198, 1919-5.

33. Miksic (1988: fig. 56; 2011a: pl. 13: inv. no. 2007.142.67, 2007.142.160 a, b). This kind of ring is said to be found in East Java (Miksic 1990: 68-9, group 65), but this place of origin is omitted in the revised edition (Miksic 2011a: 117, pl. 13).

34. Cf. the unprovenanced ring in the Museum Volkenkunde Leiden inv. no. B44-10. 35. Cf. a horn-shaped but repoussé ring with Sri letter (Dalton 1912: AF.2388= British 
the "r", a curved line at the bottom which normally swings to the right, but is depicted in reverse on the ring, and another half-circle including a central dash atop the " $i$ ". In Javanese mythology, the goddess Sri, also known as Lakshmi, is connected to the god Vishnu and stands for creative energy, fertility, wealth and fortune. She is venerated as the goddess of rice and fertility. Both the central motif of the ring and the silhouette of the water buffalo are connected to wealth and prosperity.

Cast or embossed rings with horn-shapes are recorded in Samar, Eastern Visayas in the Philippines and Central Java from the 8-13th century (Miksic 1988: 45, fig. 8: inv. no. 2007.142.49; 2011a: pl. 37; Middleton 2005: no. 117; Capristrano-Baker 2011:58-9, fig. 1.3.6; Lunsingh Scheurleer 2012:130-1). The closest parallel originates from Kebumen, Central Java (Museum Volkenkunde Leiden inv. no. 1403-3172). ${ }^{36}$ Epigraphic readings of stones set in rings from Thailand and Java with similar pronounced shoulders suggest a dating span to the 9-10th century (Wenzel 1993: 36, fig. 91-2). These comparisons assign the ring in the Frankfurt Weltkulturen Museum to the Early Classical Period.

\section{Ring with Stylized Sri Symbol}

A stylized Sri symbol is set transversally on a hoop ring with ridged sides (Fig. 10). The decorative pattern consists of half-circles set above a "w"-shape supplemented by dots and curved lines, which are mirrored to obtain a symmetrical pattern.

The closest parallel in motif and ring shape is a ring from Kedu/Temanggung in Central Java which also includes hook-shapes and beaded bands on the bezel (Museum Volkenkunde Leiden inv. no. 1794-4). The beaded bands represent typical designs in Semarang and Banyumas in Central Java. ${ }^{37}$ The stylized Sri symbol is frequently depicted in the Early Classical Period as a single or mirrored image on various ring shapes, such as on stirrup-rings, and round, dodecagonal, hexagonal or quatrefoil bezels. Among them are two rings provided with secured provenance: one from the Intan wreck and another lotus ring from Pateman (?) in the district of Purbalingga or Banyumas, Central Java, both dated to the 10th century (Eggebrecht and Eggebrecht 1995: no. 58; Flecker 2002: 72, fig. 5.95).

Frederik Bosch (1927; 1960: 117-8, pl. 35) suggested an artistic metamorphosis in the decorations of Javanese rings from the Sri letter to more elaborate patterns by extending the syllable to a stylized and symmetrically

Museum inv. no. AF.2388). It is without provenance.

36. Cf. others with a Sri letter, an elaborate Sri symbol, plain hoops or a scroll but without provenance (Stutterheim 1937: fig. 38, 39: C354, C357, C361-363).

37. Museum Volkenkunde Leiden inv. no. 1745-2, 1891-1; cf. without provenance: Frankfurt Weltkulturen Museum inv. no. 19720. 


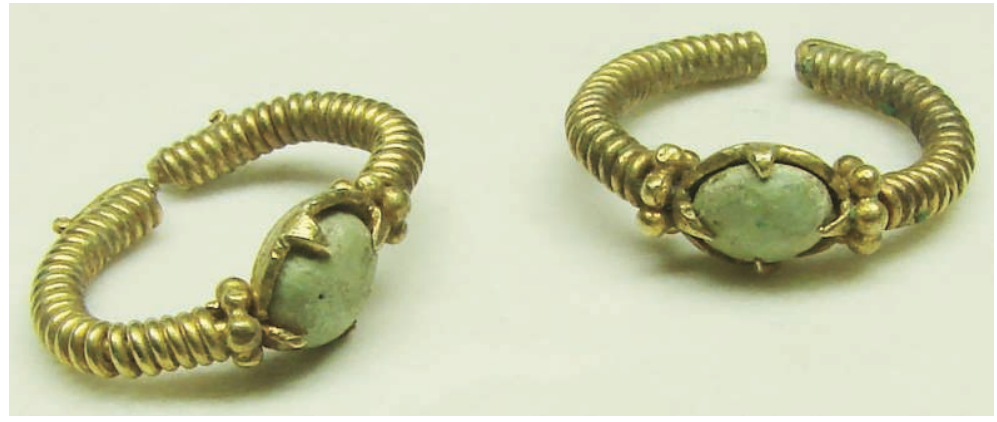

Fig. 8a-b - Frankfurt Weltkulturen Museum, inv. no. 19690 a, b. Pair of wire-wrapped ear rings encrusted with a stone and bent-over ends, Java, 200 to early 16th century.

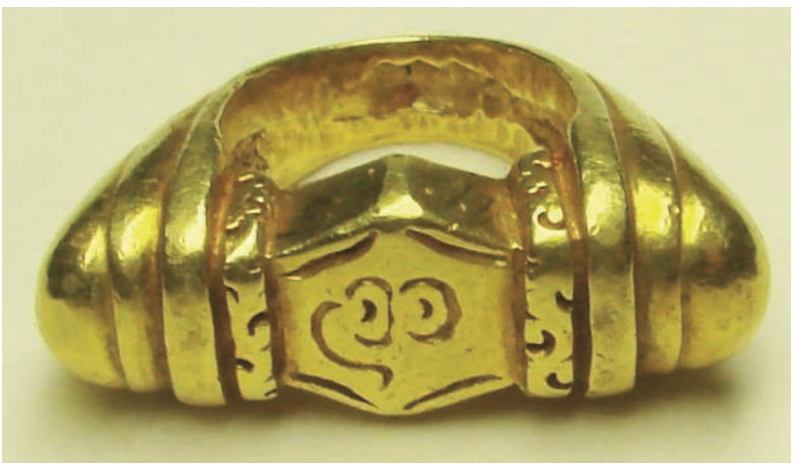

Fig. 9 - Frankfurt Weltkulturen Museum, inv. no. 19715. Horn-shaped ring with the Sri syllabel, Central Java, 9/10th century.

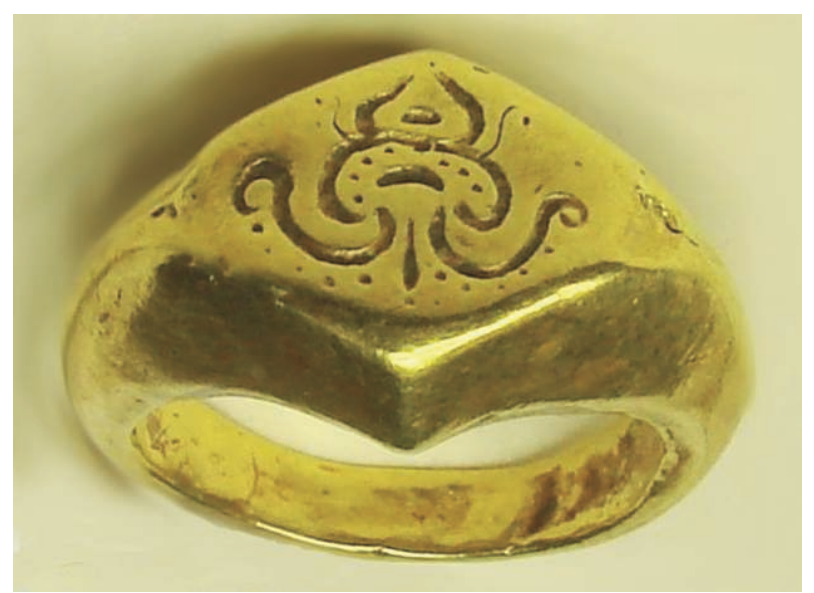

Fig. 10 - Frankfurt Weltkulturen Museum, inv. no. 19721. Hoop ring with trapezoid bezel and Sri symbol, Central Java, 9/10th century. 
arranged Sri image resembling a vase and, thereby, blending other symbolic connotations of this goddess, such as the makara, lotus, conch, fish, vase of plenty or elephant's goad (ankusha). Various scholars have followed Bosch's assumption (Miksic 1988: 14; 2011a: 130, 153; Eggebrecht and Eggebrecht 1995: no. 57; Lunsingh Scheurleer 2012: 69; Gallop 2016: 132). Bosch did not give an exact chronology, but he assumed that the evolution of the motif happened during the Javanese Hindu-Buddhist period and developed from simple to more elaborate patterns, which seems too simplistic as the sole moving factor in art history. The provenanced rings of the 10th century and other archaeological material, such as coins and intaglios which will be discussed on the following pages, suggest rather that these motifs already existed independently in the heyday of Java.

\section{Ring with Concentric Design}

The concentric design on a cast ring consists of five independent loops with some dots punched at key places in its centre (Fig. 11). This motif is documented by several cast rings from Central and West Java, suggesting a dating to the Early Javanese Period. ${ }^{38}$

Following Bosch (1927: fig. IV; 1960: 117-8, pl. 35), Lunsingh Scheurleer (2012: 69) thinks that the concentric structure is an extreme variant of the Sri letter representing a labyrinth and, thus, was used as a "lucky signet ring" in the Central Javanese Period. The courses either with no entry or with connecting paths to navigate through on the Javanese rings are indeed similar in design to the classical labyrinth, generally consisting of seven courses, in Bronze Age Europe or India, which convey a connection with redemption, Heaven or the cosmos (Kumar 2015).

A similar geometric pattern, though of rectangular shape, is found on a Central Javanese stone inscription among which Sanskrit words such as "om" are discernible (Griffiths 2012: 486). Half-round circles set above each other interpreted as Sri are punch-marked on coins from prehistoric Bhir Mound, Taxila, Pakistan, and Indian gold coins of the 10-13th century (Marshall 1975: pl. 232. no. 125, 137, 138a). The anonymous Fanam gold coin (1000-1200) of Fig. 13 combines a pair of fish with a lampstand and an ankusha on one side and with the Kannada letter Sri on the other. Still in the late 13/early 14th century Indian gold coins show the following punch-marks: a central lotus and around a conch shell, an elephant and the Sri letter (Classical Numismatic Gallery 2014: no. 79-82). The source of inspiration for the geometric pattern representing Sri is strongly connected to early South Asian motifs on coinage and intaglios.

38. Four nearly identical but larger rings come from Karangduren Tengaran and Karangmangu Cimangu Cilacap in Central Java (Museum Ranggawarsita Semarang inv. nos. 041038 and 041039), and from Ciawi, Tasikmalaya near Bandung, in West Java (two rings, Museum Volkenkunde Leiden inv. no. 1403-2831; Juynboll 1909: 183). 


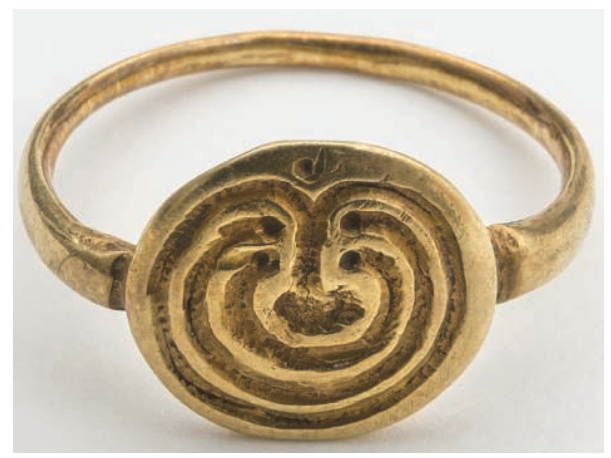

Fig. 11 - Frankfurt Weltkulturen Museum, inv. no. 19724. Bezel of a ring with concentric pattern, Central Java, 7-10th century (CEZA).
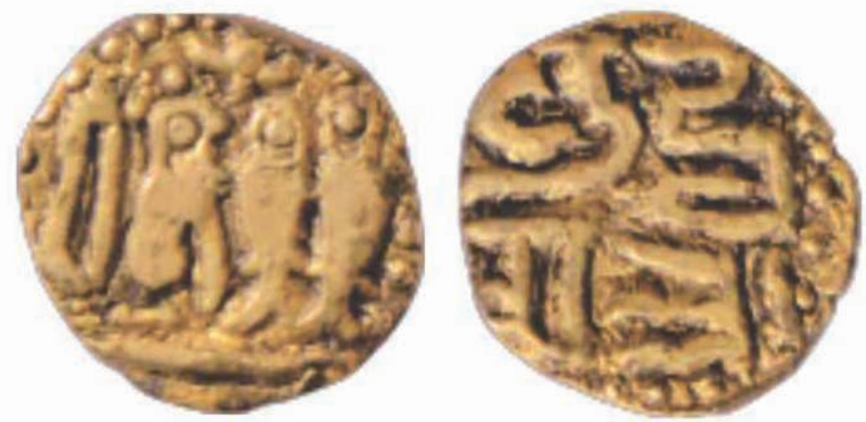

Fig. 12 a-b - Classical Numismatic Gallery 2014: no. 48. Recto/verso of a Chola gold coin (10/11th century) with a pair of fish and a Nagari legend (with courtesy of the Ahmedabad Classical Numismatic Gallery).
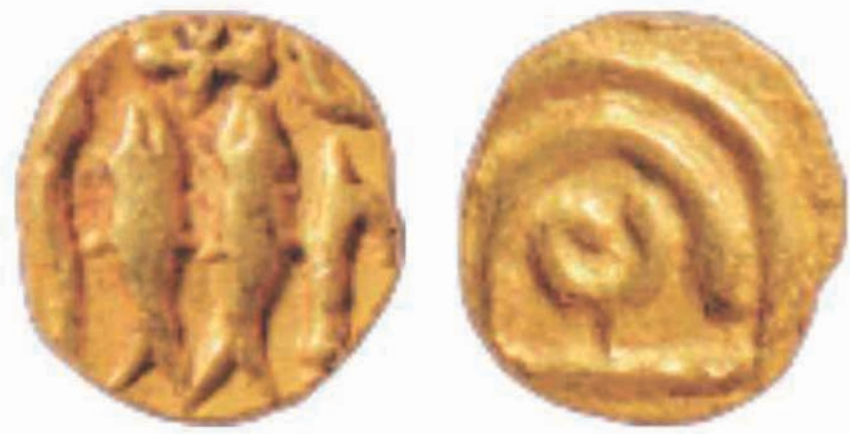

Fig. 13 a-b - Classical Numismatic Gallery 2014: no. 54. Recto/verso of a Fanam gold coin (1000-1200) with a pair of fish and the letter Sri (with courtesy of the Ahmedabad Classical Numismatic Gallery). 


\section{Ring with Fish Motif}

One ring (Fig. 14) shows a fish with an object (fly, leaf or branch?) in front of its mouth surmounted on an eight-petalled lotus. The design is characterised by a detailed depiction of the fish with sharp fins and scales, facing left and a well-balanced symmetrical arrangement of the plant with three branches. The ring is cast, but microscopic photos show the use of engraving and chasing instruments (Fig. 14b). The round disc-like bezel is enclosed by protruding shoulders as part of an ovoid-shaped hoop of planoconvex profile.

The high popularity of this motif during the early Classical Period is supported by the existence of various cast rings of similar weight with round, oval or hexagonal bezels and small variations in the motif. However, they are all without provenance. ${ }^{39}$ Provenanced parallels are documented in both Central and West Java: in Central Java, a most elaborate ring with finely carved motifs and a bulbous pearl border in positive relief from Limbangan, Wonosobo regency, and a heavy ring with a hexagonal bezel but without a beaded border from Banjarnegara (Miksic 1988: fig. 1140; Kal 1999: fig. 9; Miksic 2011a: pl. 33: inv. no. 207.142.31); in West Java: one from Serang, Banten regency (Museum Volkenkunde Leiden inv. no. B44-14) and two massive fish rings with oval bezels from Pandeglang, Banten province. ${ }^{41}$

Beyond Java, the closest similarity is to a Burmese ring of the Pyu period, which shows a fish and a crescent above wavy lines within a beaded border on a pointed ovoid bezel (Tan 2015: 163). A single or pair of fish is punch-marked on coins from prehistoric Bhir Mound, Taxila in Pakistan, and on Indian gold coins of the 10-12th century (Marshall 1975: pl. 233: no. 213-6). A Chola period (985-1014) coin assembles the pair of fish with the royal emblem of a bow, a seated tiger and an umbrella (Fig. 12, see also Fig. 13). Semi-precious stones from South Asia found in the Java Sea are also incised with the same motifs, the fish, the Sri, the vase etc. (Liebner 2014: fig. 2.3-29). A Hindu coin of medieval India, tentatively a Chola coin of king Rajaraja I (985-1014), was found in the Musi river in Palembang (Fig. 15). It shows a pair of fish with wavy lines in-between, encircled by a beaded border on one side; on the reverse a standing man with Sethu writing, probably a Tamil connection. ${ }^{42} \mathrm{~A}$

39. Cf. Stutterheim (1937: pl. 39: C338, fig. 40: C408); Miksic (2011a: pl. 33: inv. no. 207.142.19); NMW Tropenmuseum inv. no. TM-2960-262 (dated to 1300-1500); Museum Volkenkunde Leiden inv. no. B44-11, 1403-2766. Two rings in the Museum Volkenkunde Leiden (inv. no. 1403-2765, 1403-3192) originate either from Malang or the residency Purworejo, because both places, the former Dutch residencies Kedu and Bagelen, are inconsistently mentioned in the museum's inventory (Jok Leijfeldt, personal communication 10.7.2018).

40. It is wrongly addressed as Sri motif.

41. At an unknown site called Jeput in Cening, Caringin (Miksic 2011a: 255, entries 6061-2).

42. Cf. Baldwin's 2011: lot 1044. 
rock painting in Seplawan, Purworejo regency in Central Java, where a gold hoard from the 9th century was discovered, showing a pair of mirrored fishes with a circle (Soekatno 1982: 225). Bosch (1927; 1960: 117-8, pl. 35) has connected the fish on rings with the Sri letter.

However, given that the fish (matsya) in India is a symbol of luck connected to the eight auspicious symbols (asta-mangala) and is also depicted moving together with god Vishnu, it can be seen independently as an old panIndian symbol (Przyluski 1925; Karunaratne 1971; Sahai 1998). In Buddhist iconography, the fish connected to an eight-petalled lotus is a carp and a symbol of wealth and abundance (Williams 1976: 183-6).

A simple fish on a pointed ovoid bezel of a finger ring was retrieved in Limbang, West Borneo/Malaysia, dated to the 13/14th century when there were trading links between Brunei Bay and East Java (Harrison 1969: 65-6). Two fishes with curly tails one above the other are surrounded by a pearl border on a clay seal from the Majapahit period (Karow 1987: 196, no. 295). At that time, the fish applied on ceramics from Longquan could have been a source of inspiration. This kind of green ware had been exported to the Indonesian archipelago since the late 13/14th century (Dupoizat and Naniek Harkantiningsih 2007: 36, fig. 4). There is a continuity of the fish motif from the 1 st millennium until the early 16 th century. Different waves of linkages along the maritime routes existed and, hence, inspired various artistic articulations of a similar aquatic motif in gold jewellery.

\section{Rings with Vegetal Decoration}

Floral decoration provides a wealth of inspiration for gold jewellery as seen on a cast ring with a stepped bezel of hexagonal shape decorated with a central quatrefoil blossom (Fig. 16; Capristrano-Baker 2011: 62-8; Guy 2011: $177)$ and lotus rings. This type features two variations: one holds a bezel with a conical lotus flower in full bloom (Frankfurt Weltkulturen Museum inv. no. 19727), the other forms a double lotus cushion with a flat corona, such as the bezel of a large repoussé ring (Fig. 17). The latter is decorated with hatches, including dots and granules of a perfectly round shape which attain the vivid outline of thin leaves formed like spikes. The lotus bezel is set on a hoop of stirrup form and represents one of the most characteristic forms of goldwork in Javanese jewellery: a sober but prolific ring shape of high workmanship.

In a key scene on Prambanan, an encrusted lotus ring from the finger of Sita is given to Rama, her husband and the hero in this epic. The bird Jatayu holds it in his beak before he dies tragically (Golden Lotus Foundation 2017: fig. on p. 13). The bezel is provided with small claws on a double cushion set on a broad hoop with ribbed shoulders. The lotus is an important symbol in the Hindu-Buddhist context. It serves both as a seat or cushion for deities and symbolizes nobility, purity, heavenly beauty, enlightenment and rebirth. 
Lotus finger rings have large dimensions of up to $4 \mathrm{~cm}$ and bear different designs: figurative images, Old Javanese script, inlaid stones and geometric patterns, such as hatches, circles or a combination of both. They are generally assigned to the Early Classical Period (Miksic 1988: fig. 10; 2011a: pl. 36). Similarly, a ring in the Metropolitan Museum (inv. no. 1998.544.444) is dated to the 8-10th century or 8-9th century by Helen Jessup (1990: fig. 118/ no. 60) ${ }^{43}$ Two lotus rings with the Sri letter originate from Central Java: one with an ovoid bezel from the Dieng Plateau, which suggests an early dating to 700-800 (NMW Tropenmuseum inv. no. TM-3274-1), and another from Malahayu/Banjar-harjo, Brebes regency (Miksic 2011a: 256, entry 7649), whereas two others are from Pasuruan, East Java, one with simple circles and the other with an irregular grid of hatches (Museum Volkenkunde Leiden inv. no. 1785-3, 1785-10). The latter two are worked in a less refined manner than the one of the Prillwitz collection. As we will see later, because of its weight and alloy composition, the high workmanship and large size, the ring in the Frankfurt collection can be tentatively assigned to the $9 / 10^{\text {th }}$ century.

Finger-rings inlaid with stones were the most common ring type in ancient Java until the early 20th century (Jasper and Mas Pirngadie 1927: 181-4). The encrusted ring in the Frankfurt collection exemplifies the two techniques used to set gemstones in place: held by two short claws or within a cup-like base in a box setting (Fig. 18). The encrusted stones are smoothed and polished, similar to most ancient examples which are rarely facetted. ${ }^{44}$ Glass, pearls, gold beads, reused beads, ${ }^{45}$ intaglio, ${ }^{46}$ semi-precious or precious stones, even pebbles, ${ }^{47}$ were set into jewellery. According to the Ramayana Kakawin, a king wore several sparkling diamond rings, but even simple river pebbles fashioned into belts created enchanting jewelled adornments for noblewomen, as recorded in the first half of the 11th century (Soewito Santoso 1980, II: 402: XVII, 3; Creese 2004: 52). The ring in the Frankfurt collection is embellished with granulation, spirals and a triangular leaf (tumpal). This motif is attested on reliefs of the Borobudur of the 8th century and used as a terminus technicus for textile patterns in Middle Javanese poetry, such as the Kidung Wangbang

43. Cf. Stutterheim (1937: fig. 40: C400-407); Rijksmuseum inv. no. AK-RAK-1983-2. See also rings set with a stone: Museum Volkenkunde Leiden inv. no. 1403-3273; Frankfurt Weltkulturen Museum inv. no. 19726. However, none of them has a firm provenance.

44. A combination of facetted and polished stones is found on the gold plate from Plaosan, Kediri, East Java, of the $11^{\text {th }}$ century, maybe due to a replacement? (Museum Mpu Tantular inv. no. 04.1990E; Sri Soejatmi Satari 1999: 88).

45. Cf. Golden Lotus Foundation (2018: fig. on page 191 below).

46. Cf. Golden Lotus Foundation (2019: fig. on pages 82-3).

47. E.g. Frankfurt Weltkulturen Museum inv. no. 19688. 

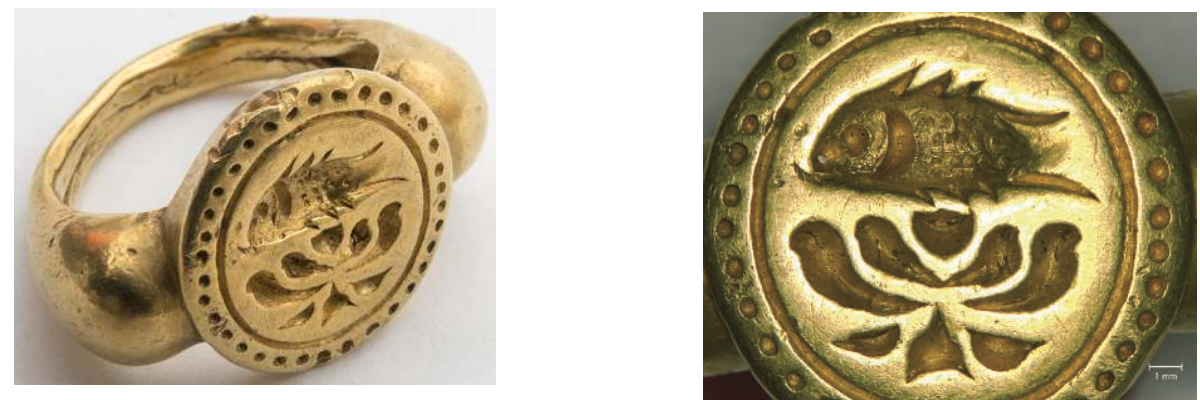

a

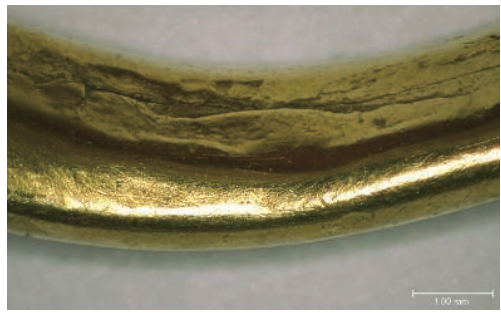

b

Fig. 14a-c - Frankfurt Weltkulturen Museum, inv. no. 19722. Ring with fish above lotus, Central Java, 9-10th century; details of the bezel and the folded hoop (CEZA).
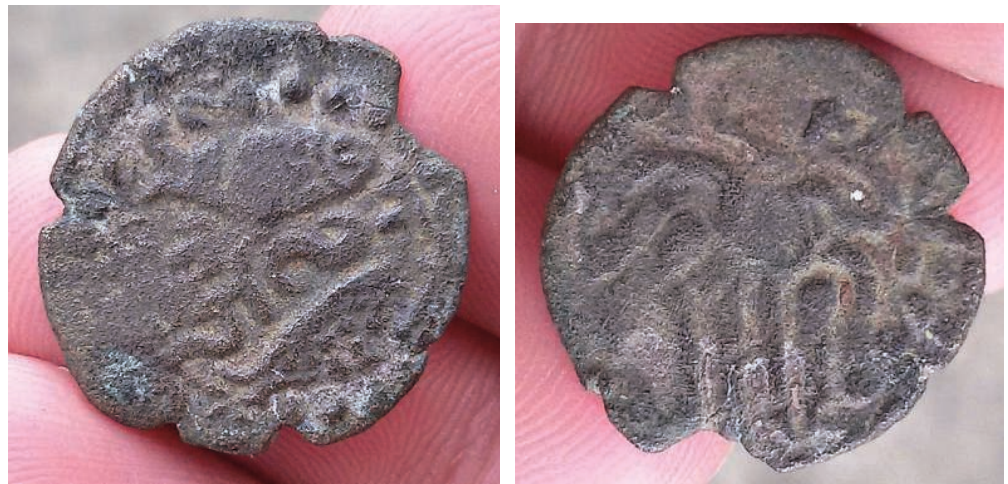

Fig. 15a-b - Okky Okta Wijaya/Wakjaya Gallery Palembang. Recto/verso of a Chola bronze coin found in Palembang, Sumatra, 10/11 th century.

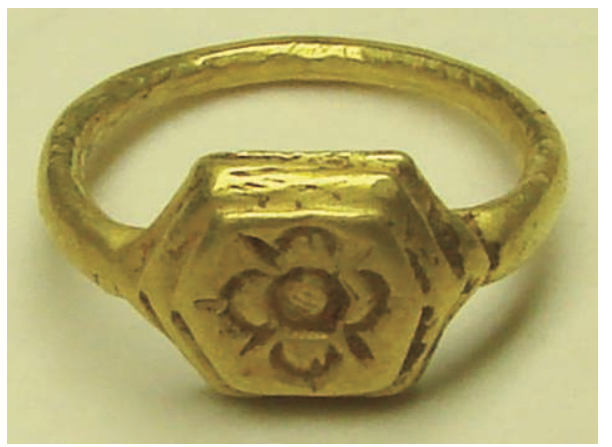

Fig. 16 - Frankfurt Weltkulturen Museum, inv. no. 19732. Ring with a four-petalled flower, Java, 7th to early 16 th century. 
Wideya ${ }^{48}$ Various rings of the early Classical Period have a folded hoop see, for example, Fig. 14c or an intaglio ring from Java with a dated Kufi inscription of the 8-11th century (Golden Lotus Foundation 2018: 181).

\section{Tiny Clips}

The tiny ornaments were once called "bird rings" by antique dealers, but there is no proof for the assertion that they adorned the legs of birds or their function was to be clipped onto the ears or hair. ${ }^{49}$ They consist of two parts and recapture design elements of finger rings: a split ring to which a vertical ornament is attached at a right angle. The horizontal part consists of a plain concentric ring (Fig. 19), a hoop with protruding shoulders set with an encrusted stone (Fig. 20) or a horn-shaped ring (Fig. 21). The latter forms a cubical bezel flanked by chased ridges and a saw-tooth band to which a solid cube with a raised triangle is soldered. The main decoration of the two others are long triangular claws which include a horizontal platform to which formerly a stone, pearl or gold bead was grasped. Ornaments which consists of a horn-shaped or plain ring and long claws for the decoration are frequently seen in various collections, but no parallel has been found for the one with the triangular motif. ${ }^{50}$ Since Willem Frederik Stutterheim (1937: 93-4, fig. 44: C653-667, C669), the shape of the claws of the tiny clips has been compared to a vajra, a thunderbolt, used in tantric Buddhist contexts. However, this comparison is misleading, because their profiles differ, and the central spike is missing. This particular claw setting was later adopted for encrusted finger-rings, attested by an example originating from Cipaku/Sukapura, West Java, tentatively dated to the $13 / 14^{\text {th }}$ century (National Museum of Indonesia 2013: 94).

The earliest parallels of this kind of tiny clips were unearthed at $U$ Thong and at the pre-Srivijayan site of Air Sugihan (Agustijanto Indradjaja et al. 2015: photo 31; Bennett 2017: 104-5). At Kamhantik in Mulanay, Quezon province, the Philippines a similar clip was unearthed in sarcophagus 14 (Dizon 2015). Following Miksic (1988; 2011a: pl. 43), the four examples in the Frankfurt Weltkulturen Museum, are assigned to the Early Javanese Period. This dating is supported by the provenance of several examples from Central Java, some from Kedu. ${ }^{51}$

48. Robson (1971: e.g. 197, 221); Miksic (2011a: 165). However, scholars like Pauline Lunsingh Scheurleer and Marijke Klokke (personal communication 12.4.2017) avoid this term in an ancient context.

49. Pauline Lunsingh Scheurleer, personal communication 12.4.2017.

50. Miksic (1988: pl. 24: inv. no. 26; 2011a: pl. 43: inv. no. 2007.142.242, 2007.142.243, 2007.142.256, 2007.142.257, 2007.142.255); NMW Tropenmuseum inv. no. TM-1771-19. A nearly identical piece with similar long claws is stored in the NMW Tropenmuseum (inv. no. TM-2960-306).

51. Museum Volkenkunde Leiden inv. no. 1403-3272, 1920-9; cf. without provenance: 


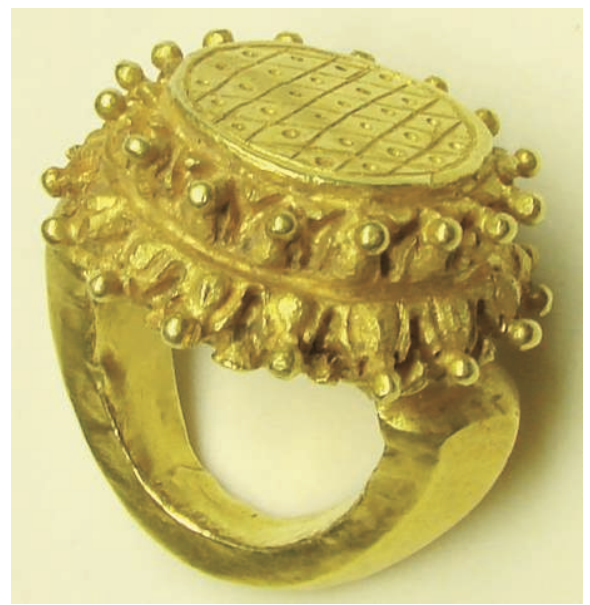

Fig. 17 - Frankfurt Weltkulturen Museum, inv. no. 19714. Large lotus ring, Central Java, 9/10th century.

Fig. 18 - Frankfurt Weltkulturen Museum, inv. no. 19749. Ring with encrusted stones and "tumpal" motif, Central Java, 7-10th century.

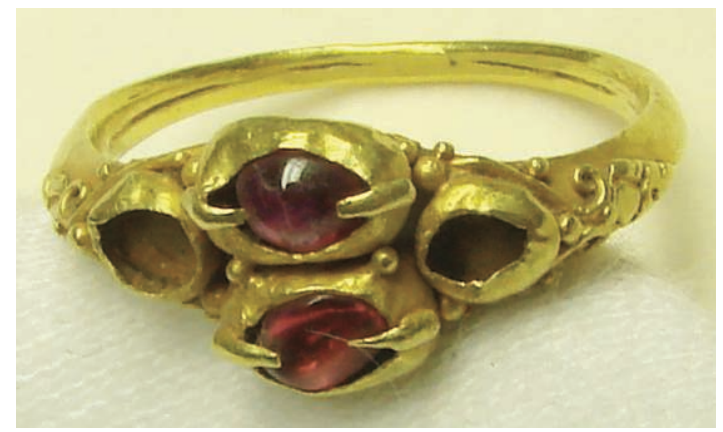

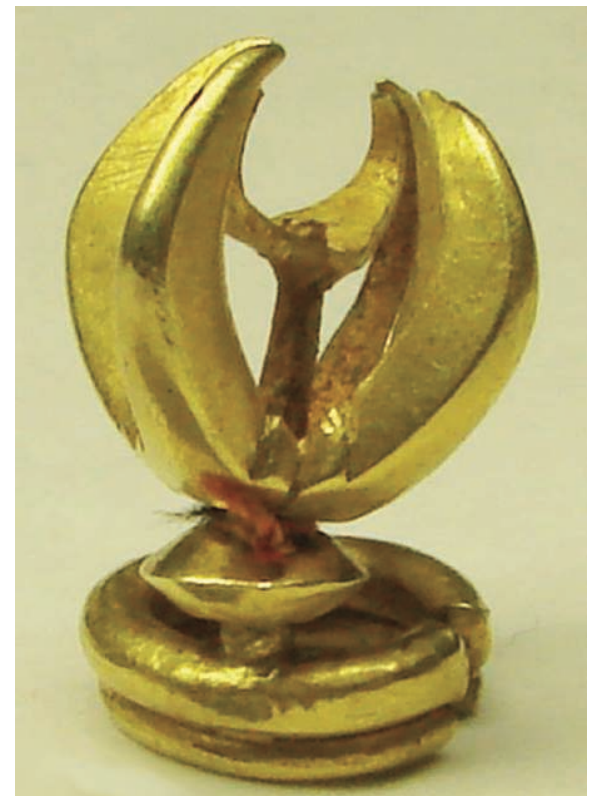

Fig. 19 - Frankfurt Weltkulturen Museum, inv. no. 19770. Tiny clip with claws, Central Java, 7-10th century.

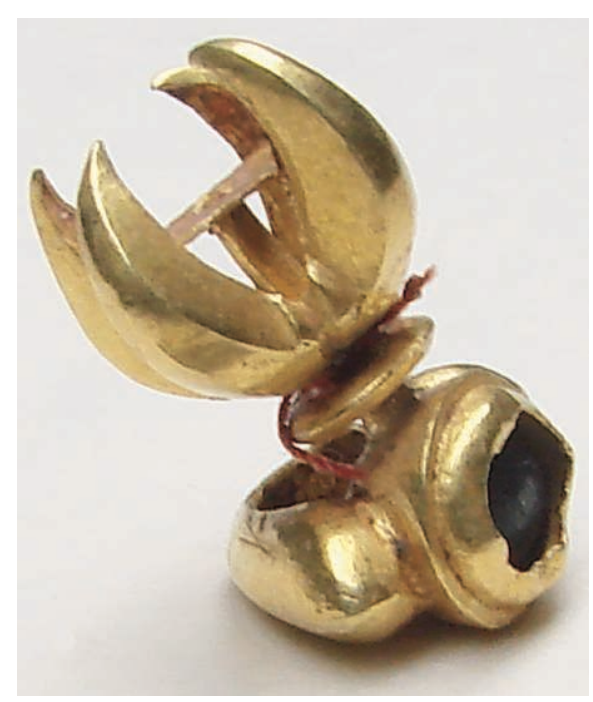

Fig. 20 - Frankfurt Weltkulturen Museum, inv. no. 19768. Encrusted tiny clip with claws, Central Java, $7-10$ th century. 


\section{Ear Ornaments with Bezels}

Various types of ear ornaments in the Frankfurt collection can be distinguished according to the outline of the main motif and the shape of the shank. Some of them consist of two parts: a stepped bezel of hexagonal shape and asymmetrically arranged shanks, a shorter and a longer one (Fig. 22-23). Their hexagonal bezel is either plain or raised with a triangle. The hemispheres of swelling forms on the shoulders recapture design elements of rings.

An example which lacks provenance and is broadly dated to 750-1550 (NMW Tropenmuseum inv. no. TM-2960-288) is identical to Fig. 22. Miksic (2011a: pl. 47-8) assigns this kind of ear ornament to the Early Classical Period. His assumption can be asserted on various grounds: parallels from Purbalingga, Banyumas, Central Java (Museum Volkenkunde Leiden inv. no. 1403-2678, 1403-2679), stylistic similarities to motifs of the Early Classical Period of those found on the tiny clips mentioned above, and the swelling forms in stone carving (Lunsingh Scheurleer 1994). ${ }^{52}$ One ear ornament from East Java (Miksic 2011a: pl. 48: inv. no. 2007.142.106) is similar to three examples in the Prillwitz collection including Fig. 23 (Frankfurt Weltkulturen Museum inv. no. 19649, 19651), though the latter are without provenance.

\section{Eardrops}

This kind of ear ornament - henceforth called eardrops because of the textual references - is represented by four different types in the collection. They all consist of a "u"-shaped and curved shank, which serves as a counterweight and facilitates the attachment to the earlobe.

Firstly, an unknown example with rows of pyramidal shapes could be the visualisation of the spiky skin of a fruit or an artistic interpretation of geometric shapes (Fig. 24). The front explores a vibrant surface designed with the utmost artistic understanding of repetitive pyramidal shapes creating a spiky outline, whereas the back of the shank is left blank. Similar concepts of decoration have been seen on other gold jewellery, such as rod finials, for example, from Palembang, stored in a private collection in Jakarta, and in the Museum Volkenkunde Leiden (inv. no. 03-1856). A barrel-shaped gold bead from Tayawtaw, Myanmar, shows a similar spiky outline (Mahlo 2012: app. 22), but none of the examples represents a true parallel.

Secondly, another eardrop of " $u$ "-shape shows a central bud surrounded by vegetal forms and loops congruent on both parts of the "u"-shape (Fig. 25). Nearly identical parallels, even of the same size, are controversially dated to the 8-12th (Metropolitan Museum inv. no. 2001.794.203, 2001.794.208) or

Stutterheim (1937: fig. 41: C655); NMW Tropenmuseum inv. no. TM-2960-306, TM2960-307, TM-1771-19.

52. Cf. without provenance: Stutterheim (1937: fig. 42: C579, C581). 
14-15th centuries (NMW Tropenmuseum inv. no. TM-2960-279, 2960-282), though all lack any provenance. The Late Classical Period is also suggested by Miksic because of a similar pair from East Java (2011a: pl. 103: inv. no. 207.142.359 a, b).

Thirdly, eardrops are decorated with figurative motifs, such as animals and mythical figures. They are found in pairs. ${ }^{53}$ One represents a mythical creature which combines the features of an elephant with a raised trunk, tusks and an open mouth with vegetal motifs and other zoomorphic elements, such as pointed horns or ears (Fig. 26). A pair of eardrops depicts a ram's head with curved horns, locks and dashed eyebrows. Although modelled in a most naturalistic way, the head is extended vertically by flamelike foliage featuring a purely imaginary creature (Fig. 27). The dating to the Late Classical Period for this kind of ear decoration is not disputed, although none of the objects in pre-war museum collections has a firm provenance. ${ }^{54}$ Lunsingh Scheurleer (2012: 79) is of the opinion that the images of the ram and elephant represent "protective motifs", in particular, the ram features a "symbol of muscular might" dated to the second half of the 14th century.

Fourthly, in striking contrast to jewellery pieces which create a highly vibrant outline, others take an austere shape of hexagonal profile inlaid with a cabochon held in place by four thin clasps (Fig. 28). A nearly identical pair encrusted with red stones originates from Tulungagung, East Java (Miksic 2011a: pl. 96: inv. no. 2007.142.262 a, b). Miksic's dating is not debated, so we also assign the pair in the Frankfurt Museum to the Late Classical Period.

\section{Fan-shaped Ear Ornament}

A fan-shaped ear ornament with leaves, spirals and pointed projections has only one shank. The decoration is displayed parallel to the shank, whereas the decoration of the former type is arranged perpendicular to the shank (Fig. 29). It was assumed that it has to be hooked either into a pierced earlobe or the helix (Lunsingh Scheurleer 2012: 53). This ear ornament is found in pairs. ${ }^{55}$ Whereas some scholars are of the opinion that this form was inspired by animal forms similar to a beetle or butterfly-like insect with outspread wings in nature, others think that it originated from vegetal forms such as a lotus bud or opened nut (Juynboll 1909: 187; Eggebrecht and Eggebrecht 1995: no. 87; Lunsingh Scheurleer 2012: 53).

53. E.g. Linden-Museum Stuttgart inv. no. SA 37308 a, b.

54. Ear ornaments in the shape of an elephant: Stutterheim (1937: C646); Lunsingh Scheurleer (2012: no. 20, republished in de Bock 2014: 248-9); NMW Tropenmuseum inv. no. TM-1771-15; ear ornaments with a ram: Stutterheim (1937: fig. 42: C645); Lunsingh Scheurleer (2012: no. 21).

55. E.g. Stutterheim (1937: C604, fig. 42: C605). 


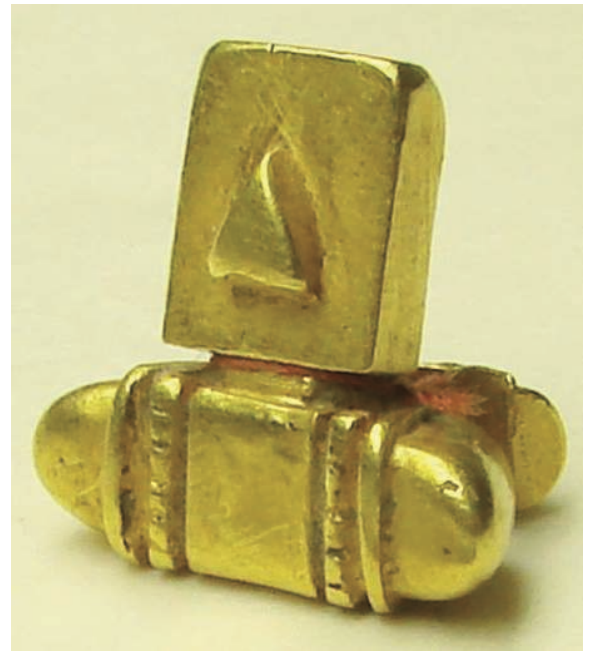

Fig. 21 - Frankfurt Weltkulturen Museum, inv. no. 19705. Tiny clip with horn-shaped ring and triangle, Central Java, 7-10th century.

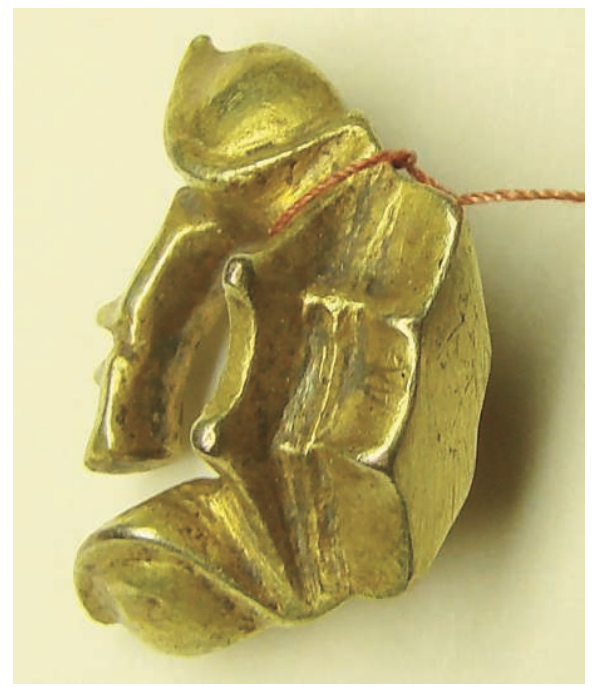

Fig. 23 - Frankfurt Weltkulturen Museum, inv. no. 19653. Ear ornament with hexagonal bezel, Java, $7-10$ th century.

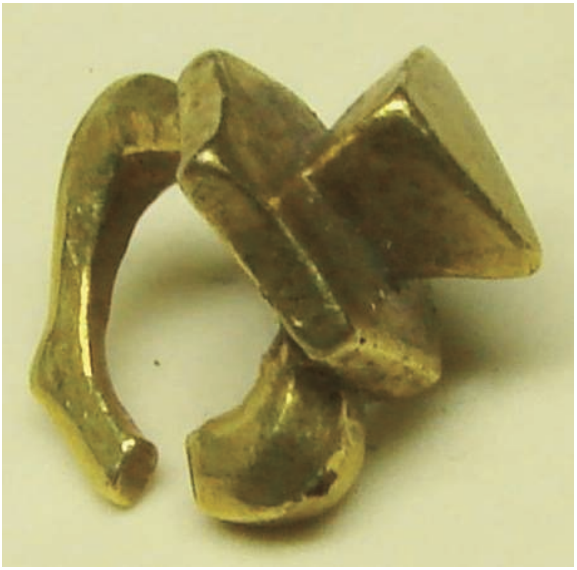

Fig. 22 - Frankfurt Weltkulturen Museum, inv. no. 19648. Ear ornament with triangle on bezel, Java, $7-10$ th century.

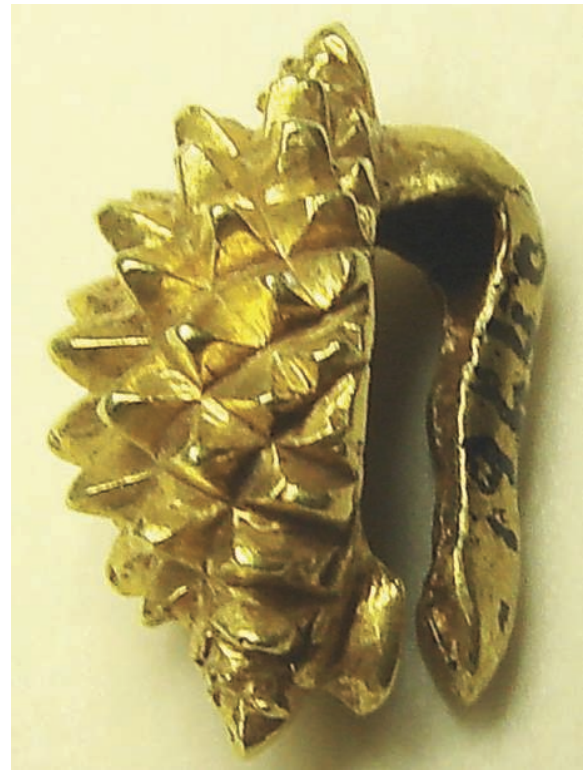

Fig. 24 - Frankfurt Weltkulturen Museum, inv. no. 19647. Spiky eardrop of "u"-shape, Java, 11th to early 16 th century 


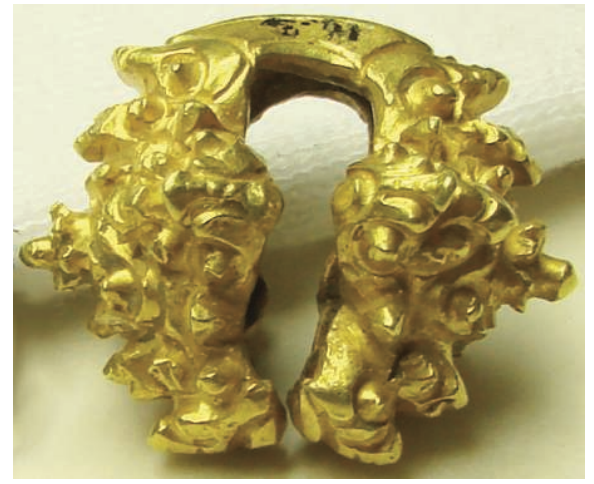

Fig. 25 - Frankfurt Weltkulturen Museum, inv. no. 19668. Eardrop of "u"-shape with foliage, Java, 11 th to early 16 th century.

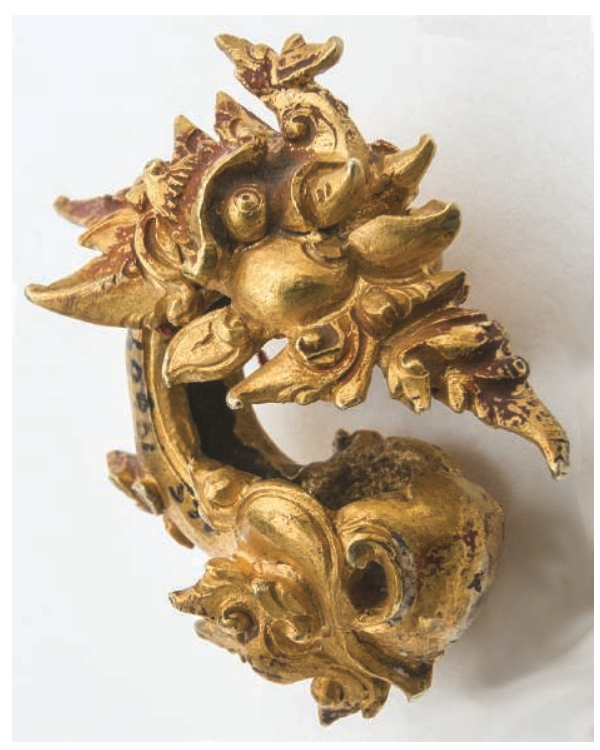

Fig. 26 - Frankfurt Weltkulturen Museum, inv. no. 19664. Eardrop of "u"-shape with mythical beast, Java, 11 th to early 16 th century.
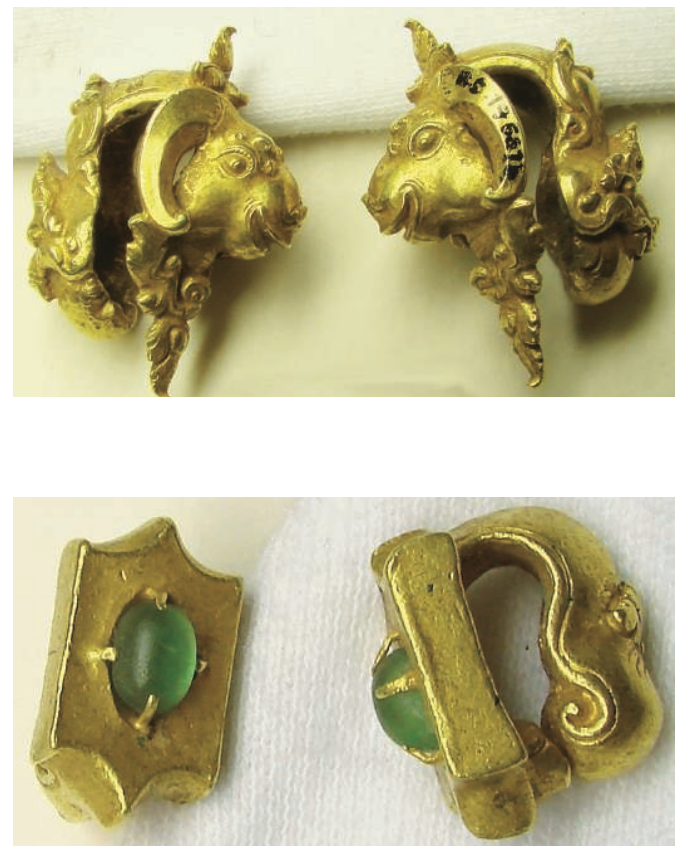

Fig. 27 a-b - Frankfurt Weltkulturen Museum, inv. no. 19667 a, b. Pair of eardrops of "u"-shape with mythical beasts, Java, 11 th to early 16 th century.

Fig. 28 a-b - Frankfurt Weltkulturen Museum, inv. no. 19645 a, b. Pair of encrusted eardrops of "u"-shape, Java, 11th to early 16 th century. 
The dating is also highly debated and ranges from the Central to the East Javanese Period. ${ }^{56}$ Lunsingh Scheurleer (2012: 53) favours the Central Javanese Period, whereas Miksic (1988: group 62, PC174) dates it to the 11-12th century. The NMW Tropenmuseum (inv. no. TM-2960-277, TM-1771-11) suggests a different dating range for two versions of the same type to 700-1550 and to 900-1550. The Metropolitan Museum (inv. no. 1998.544.134, 1998.544.133, 1998.544.136, 1998.544.137, 2001.794.64) even proposes three different time periods between the 8th and the last quarter of the 15th century. One earring of this type originates from Banyumas, Central Java, and is dated to 750-930 (Museum Volkenkunde Leiden inv. no. 1403-2676), whereas two others are recorded from Madiun, East Java (Museum Volkenkunde Leiden inv. no. 18001; Miksic 1988: group 62; 2011a: pl. 99: inv. no. 2007.142.173). ${ }^{57}$ A Borobudur relief indicates that these fan-shaped ear ornaments were worn in the 9th century (Golden Lotus 2019: fig. on p. 47). It is thus impossible to attach the item of the Frankfurt Museum unambiguously to a specific time period.

\section{The Mastery of Goldsmithing}

The skill of goldsmithing was highly esteemed in ancient Javanese society, listed among the five main crafts (Rani 1957: 89, 98, stanza 29, 43; Miksic 2011a: 32-3; Timbul Haryono 2012). By the end of the 10th century, goldsmiths and other specialists, such as jewellery dealers, makers of bangles, shields or wire, were full-time professionals who moved from market to market. Some of them were given leave to trade tax-free (Christie 1998: 349$50,371-3)$. The alchemy was a secret formula and endowed goldsmiths with special power. According to the Pararaton of the 15th century, Ken Angrok, crowned in 1222, learned the science of making gold which he as ruler could then redistribute to his subjects (Hall 2000: 89-90).

Different idioms existed in old Javanese to refer to goldwork in connection to its uses, geographic references and material qualities, such as the colour, alloy or physical state (Zoetmulder 1982). There are expressions for pure or melted gold, gold dust, gold leaf, paint or an alloy of gold and copper applied to carvings in a pavilion and on krises (Zoetmulder 1982, I: 11168:17; Hinzler 1999: 30). The four ways in which the purity of gold can be tested given in the old Javanese didactic text Kakawin Ślokäntara, which was copied and compiled in Bali in 1753 - by rubbing on a touchstone, beating or hammering, cutting or melting - even served as metaphors for human qualities and virtues

56. Miksic (2011a: 242, pl. 99) and Eggebrecht and Eggebrecht (1995: no. 87) contra Lunsingh Scheurleer (2012: 53); All these objects are without provenance.

57. Cf. without provenance: Eggebrecht and Eggebrecht (1995: no. 87); Miksic (2011a: pl. 99: inv. no. 2007.142.172); G. K. (1984: 35, fig. on p. 29); the ear ornament (Museum Volkenkunde Leiden inv. no. 1403-2678) in Lunsingh Scheurleer (2012: 53: ft. 4) is another jewellery type. 
(Rani 1957: 117, stanza 80). Textual references to the processing of gold and its compositions are available in other parts of Southeast Asia but not for Java (Bennett 2009: 101-2; 2017: 53-4; Estrella 2016: 64-5).

Decoration techniques in the kakawin poetry of Classical Java included chased gold, gold leaf, open-work and "cupped" or soldered (?) stone settings (Robson 1971: 149, 167, 175, 197, 235; Creese 2004: 151, 157). Their aesthetic appeal is expressed by the shine of glittering, colourful and luminous jewellery described as "brilliant" and "sparkling" (Soewito Santoso 1980, II: 392: XVI, 9; 402: XVII, 3). Female beauty is compared with "burnished gold" in the 11th century (Creese 2004: 60). The poets were dazzled by the glow of diamonds, resembling dots of powder which framed the chain worn across a princess's breasts. The colour described as "dazzling" and "constant light from the ever-gleaming" gold features as an important aesthetic quality in Balinese kakawin literature of the 19th century which reflects Old Javanese ideas of the cosmological association of gold (Creese 2004: 44, 149, 151). Gold was connected to the sun, rainbows and light, and jewels, and particularly to the water of life. The brilliant shine of gold when heated, used as a metaphor in the Kakawin Ślokäntara, was a sign of the inherent goodness of the excellent (Rani 1957: 113, stanza 75). The most commonly used gold was, thus, of yellow colour, although red gold was also known and served for decorations interspersed with precious stones in the 9th century (Soewito Santoso 1980, II: 452: XIX, 17). The colour of gold paintings on walls and gateways was treated with a liquid called sepuh, as known from the 11th century work Arjuna Wiwaha Kakawin. It is a mixture of alum, saltpetre, blue stone (probably Lapislazuli) and other materials which turn the gold to a darker colour (Hinzler 1999: 30). In the ethnographic context, coating recipes were widely used to highlight the engraved design (Veltman 1904: 7). It is not known whether the reddishbrown stains of iron on some of the gold objects in the Frankfurt Weltkulturen Museum (Fig. 1, 10; Frankfurt Weltkulturen Museum inv. no. 19732, 19644) or red pigments, as seen on the earring (Fig. 28) or on a Central Javanese hoop ring with a Sri sign from Semarang (Museum Volkenkunde Leiden inv. no. 1745-2), are the remains of coating from ancient or more recent times or have developed from post-depositional conditions. ${ }^{58}$ Anna Bennett (2017: 77) assumes that the red patina on excavated artefacts derives from the deposition of metal ions from the groundwater.

Very few archaeometallurgical analyses have been conducted on the alloys used in ancient metalwork in Southeast Asia. The first compositional analysis of gold started in the early 1960s. In Sumatra, 26 objects from Kota Cina, including a ring fragment, reveal certain types of alloys according to specific kinds of objects and manufacturing techniques (Manning et al. 1980; Swan and Scott

58. See the mineralogical and chemical studies of red stains on jewellery from Classical Java: Brenker (2019); Friedrich (2019). 
1986: 269-70). There were several clay cups containing remains of borax at the same site (Miksic 2013: 125). It was utilised as a flux (nitrate or carbonate, e.g. calium nitrate) ${ }^{59}$ in melting gold and cementation, a process to remove silver as silver chloride and raise the purity of the gold. Josef Riederer $(1994,1999)$ has analysed around 100 objects from Java, now stored in the Yale University Art Gallery, among which fewer than 40 deliver verifiable data of the gold content. ${ }^{60}$ Data for prehistoric gold excavated in Bali, Cambodia and Vietnam have been mainly advanced in the last few decades, but the comparative data for gold from the historical period is still limited in Southeast Asia. ${ }^{61}$ There are profound data of gold jewellery from private collections, but not a single chemical analysis of Java gold is available which derives from a controlled archaeological excavation (Lockhoff 2018; Pernicka 2018).

\section{Chemical Composition}

A total of 25 pieces of gold jewellery from the Weltkulturen Museum were analyzed to determine gold $(\mathrm{Au})$, silver $(\mathrm{Ag})$, copper $(\mathrm{Cu})$, zinc $(\mathrm{Zn})$, lead $(\mathrm{Pb})$ and iron (Fe) concentration by ED-XRF (Fig. 30, Table 1; CEZA 2016). This method helps to identify different types of gold alloys consisting of different amounts of gold, silver and copper. Results show that the silver concentration varies between 3.8 and $48 \% \mathrm{Ag}$, and the copper concentration between 0.2 and $10.5 \% \mathrm{Cu}$. Different alloys can be depicted graphically in a so-called ternary diagram. In Fig. 30 the results of the 25 analyzed pieces from the Weltkulturen Museum are plotted and three different groups can be identified.

The majority of the objects consist of around 15-25\% Ag. However, three pieces characterized by less silver fall out of this general range. The braided filigree ring of the Early Javanese Period and two encrusted ear ornaments of the Late Javanese Period are made from an alloy with less than $10 \%$ silver content and a lower copper content than all the other objects (Fig. 5, 28 $\mathrm{a}-\mathrm{b}$ ). The third group shows high silver concentrations up to $48 \%$. Under the microscope silvery stains underneath the golden surface indicate that these pieces are gilded.

59. Alternatively, sodium chloride or saltpetre can be used.

60. In Riederer's table 2 of 1994, two samples lack inventory numbers and one ring (inv. no. PC098) cannot be traced. The data set was kindly made accessible by Hunter Thompson, Ruth Barnes, Benjamin Diebold and Thomas Jaffe at the Yale University Art Gallery.

61. Schlosser et al. (2013); Calo et al. (2015); XRF analyses of South Asian jewellery in Singapore (Yeow 2007: 272-3); three gold objects excavated at the Philippine Kamhantik site of the 10-14th centuries yielded the following results (Dizon 2015): a tiny clip contains $90 \%$ gold, $9 \%$ silver and $1 \%$ copper; a coiled ring contains $69 \%$ gold, $27 \%$ silver, $4.8 \%$ copper; and a link contains $90 \%$ gold, $9 \%$ silver, $1 \%$ copper. 
Firstly, during the Early Javanese Period, cast objects of both finger rings and ear ornaments with auspicious symbols tend to contain a relatively high gold content between $80-90 \%, 8-17 \%$ silver and 2-5\% copper (Fig. 10, 14 a-c, 21). This group consists of a horn-shaped form and the Sri motif. This result confirms Riederer's observation that cast finger rings with inscriptions, the fish or Sri motif typical of the Early Javanese Period, are made of better quality gold. Among his seven evaluable composition analyses, the amount of gold is between $61-86 \%$ and that of silver between $14-17 \%$.

The rings with auspicious signs in our first alloy group represent simsim pasāda/prasāda gold rings of the 9/10th centuries. This assumption is grounded not only by the chemical analyses given and stylistic considerations but also by their standardised weights. The highest weight unit of this kind of gift of four gold weights is represented in the form of rings of one suwarna or 16 maşa (38 g), others are graded lower - of eight, six, four or only two masa, based on the standard unit of one maşa of $2.4 \mathrm{~g}$ (Christie 1993). The second gradation of ring weight that is most frequently listed is eight maşa or $19 \mathrm{~g}$ which among our first alloy group corresponds to the ring with the fish motif of $19.6 \mathrm{~g}$ (Fig. 14). In three sima inscriptions of 875-901, the third ring weight features four maşa (9 g) and in a Central Javanese inscription of 882 the fourth ring weight features two maşa $(4.5 \mathrm{~g})$ which roughly correlates to the hoop ring with the decorative Sri motif of $4.27 \mathrm{~g}$ (Fig. 10). As the motifs on these rings are closely connected to South Asian motifs found on coins and intaglios, their "Sinhalese-style" could offer more confirmation of this assumption. More rings with a flattened bezel and auspicious symbols or script ${ }^{62}$ might be assigned to this category of these propitiatory gifts gold rings if more information on the alloys becomes available. One gold ring (19.5 g) in a private collection with a fish above a lotus corresponds to 8 mass $a$ and also consists of a relatively high gold content of $89 \%$ gold, $8 \%$ silver and 3\% copper (Tjoa-Bonatz 2018: 57, fig. 4; Golden Lotus Foundation 2018: fig. on p. 81). The horn-shaped ring with the Sri symbol corresponds to one suwarņa or 16 maşa (Fig. 9), the lotus ring to eight maşa (Fig. 17). Both contain more than $80 \%$ gold but varying silver content. Despite the small sample and the fact that there are rings which correspond to the maşaweight but contain a relatively low gold content, ${ }^{63}$ the results suggest that this type of auspicious ring was standardised both in its weight and gold composition and, thus, carried a monetary value. Simsim pasāda/prasāda are not only cast but are also made of a combined technique of cast parts and gold sheet: the bezel of the lotus ring is hollow (Fig. 17).

62. See, for instance, the inscription rings in Kusen (1983); Machi Suhadi (1999); Griffiths (2012: 489-93); unfortunately, none provides weights.

63. The small rings, one with the flower and the other with a geometric pattern, correspond to the lowest weight group of about one maşa (Fig. 11, 16). 


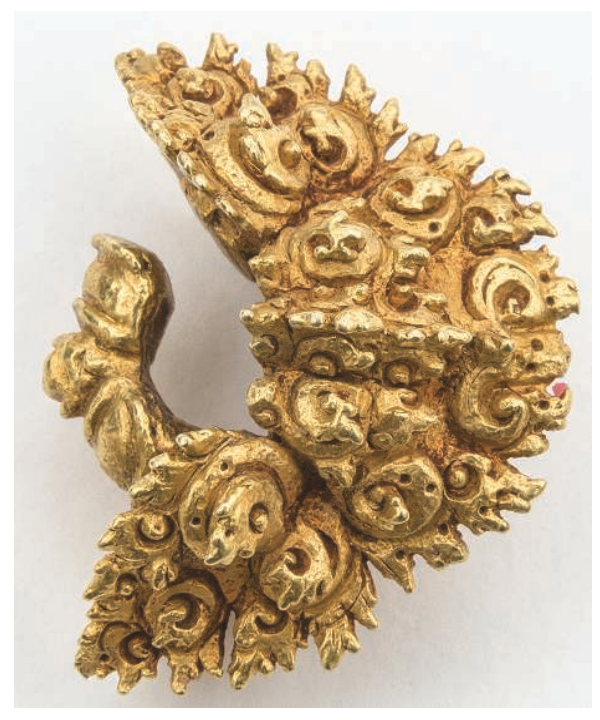

Fig. 29 - Frankfurt Weltkulturen Museum, inv. no. 19670. Fan-shaped ear ornament, Java, 7th to early 16 th century.

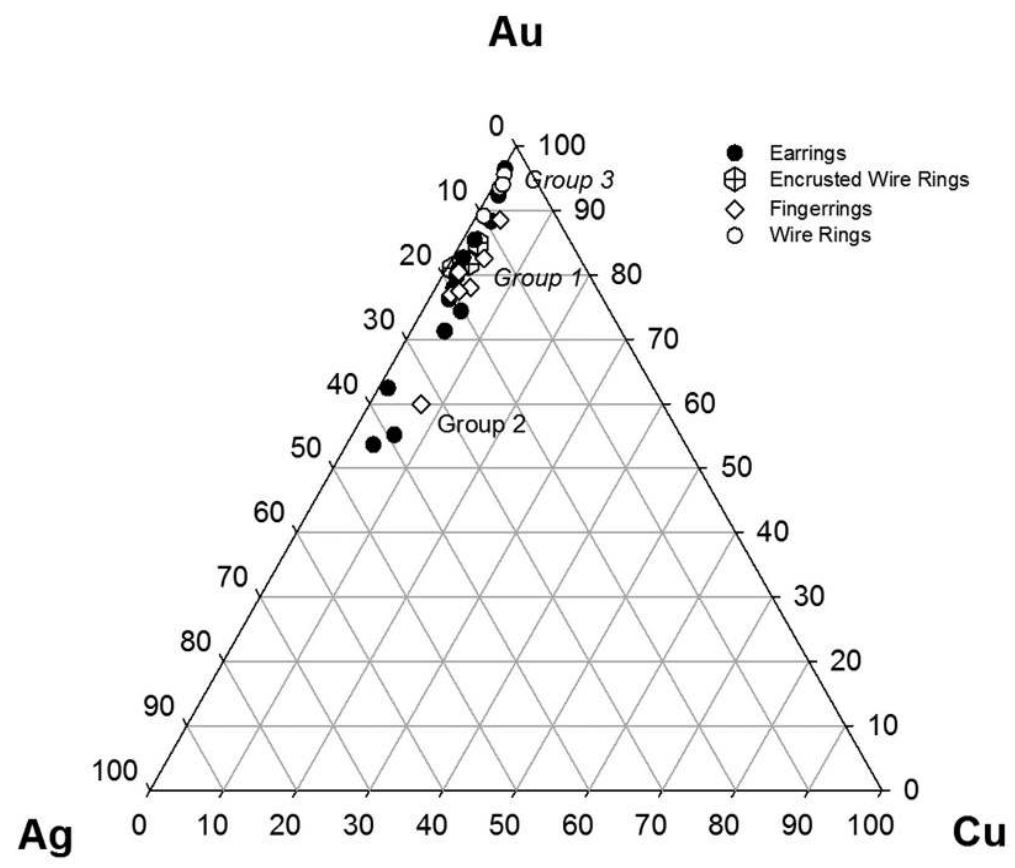

Fig. 30 - The ternary diagram shows the alloy composition of 25 Java jewellery from the Frankfurt Weltkulturen Museum: $\mathrm{Au}=$ gold, $\mathrm{Ag}=$ silver, $\mathrm{Cu}=$ copper (CEZA). 
Table 1 - Chemical composition, weight and size of jewellery from the Weltkulturen Museum analysed by energy-dispersive $\mathrm{x}$-ray fluorescence spectrometry (ED-XRF).

All chemical results are given in mass-\%. n.d means not detected.

\begin{tabular}{|c|c|c|c|c|c|c|c|c|c|}
\hline $\begin{array}{c}\text { Lab- } \\
\text { no. } \\
\text { (MA-) }\end{array}$ & Inv. no. & Weight (g) & Size $(\mathbf{c m})$ & Au & Ag & $\mathrm{Cu}$ & Zn & $\mathbf{P b}$ & $\mathbf{F e}$ \\
\hline \multirow{10}{*}{130901} & 19645a_a & \multirow{10}{*}{$\begin{array}{c}25.5 \\
\text { (together) }\end{array}$} & \multirow{10}{*}{$1.6 \times 1.7 \times 0.9$} & 92 & 6.1 & 1.4 & n.d. & n.d. & 0.34 \\
\hline & 19645a_b & & & 92 & 6.1 & 1.3 & n.d. & n.d. & 0.33 \\
\hline & 19645a_c & & & 85 & 8.1 & 5.8 & n.d. & 0.66 & 0.4 \\
\hline & 19645a_e & & & 92 & 6.2 & 1.2 & n.d. & n.d. & 0.43 \\
\hline & 19645b_a & & & 92 & 6.2 & 1 & n.d. & n.d. & 0.26 \\
\hline & 19645b_b & & & 92 & 6.3 & 1 & n.d. & n.d. & 0.26 \\
\hline & 19645b_c & & & 86 & 9.5 & 3.8 & n.d. & n.d. & 0.31 \\
\hline & 19645b_d & & & 87 & 9 & 3.6 & n.d. & 0.19 & 0.45 \\
\hline & 19645b_e & & & 91 & 6.1 & 1.7 & n.d. & n.d. & 0.63 \\
\hline & 19645b_f & & & 91 & 6.3 & 1.5 & n.d. & n.d. & 0.51 \\
\hline \multirow{3}{*}{130902} & 19647_a & \multirow{3}{*}{1.31} & \multirow{3}{*}{ 1: 1.4} & 74 & 20.3 & 5.1 & n.d. & n.d. & n.d. \\
\hline & 19647_b & & & 74 & 20.4 & 5.5 & n.d. & n.d. & n.d. \\
\hline & 19647_c & & & 72 & 22.2 & 5.8 & n.d. & n.d. & 0.14 \\
\hline \multirow{5}{*}{130903} & 19648_a & \multirow{5}{*}{2.51} & \multirow{5}{*}{$1.2 \times 1.1 \times 1$} & 53 & 42.8 & 4 & n.d. & n.d. & n.d. \\
\hline & 19648_b & & & 54 & 37.6 & 7.8 & n.d. & n.d. & 0.14 \\
\hline & 19648 _c & & & 54 & 43 & 3 & n.d. & n.d. & n.d. \\
\hline & 19648_d & & & 54 & 42.2 & 4 & n.d. & n.d. & n.d. \\
\hline & 19648 e & & & 59 & 38.2 & 3 & n.d. & n.d. & n.d. \\
\hline \multirow{4}{*}{130904} & 19653_a & \multirow{4}{*}{6.33} & \multirow{4}{*}{ h: 2} & 57 & 37 & 5.8 & n.d. & n.d. & n.d. \\
\hline & 19653_b & & & 54 & 39.7 & 6 & n.d. & n.d. & n.d. \\
\hline & 19653_c & & & 53 & 41.1 & 5.8 & n.d. & n.d. & n.d. \\
\hline & 19653_d & & & 63 & 29.3 & 4.2 & n.d. & n.d. & 3 \\
\hline \multirow{5}{*}{130905} & 19664_a & \multirow{5}{*}{12.75} & \multirow{5}{*}{ h: $2.7, \mathrm{w}: 2.7$} & 59 & 39.2 & 1.4 & n.d. & n.d. & 0.14 \\
\hline & 19664_b & & & 38 & 58.1 & 3.2 & n.d. & n.d. & 0.16 \\
\hline & 19664_c & & & 38 & 58.7 & 3.7 & n.d. & n.d. & n.d. \\
\hline & 19664_d & & & 58 & 33.2 & 1.5 & n.d. & n.d. & 7.30 \\
\hline & 19664_e & & & 65 & 33.4 & 1.1 & n.d. & n.d. & 0.3 \\
\hline
\end{tabular}




\begin{tabular}{|c|c|c|c|c|c|c|c|c|c|}
\hline $\begin{array}{c}\text { Lab- } \\
\text { no. } \\
\text { (MA-) }\end{array}$ & Inv. no. & Weight (g) & Size (cm) & Au & Ag & $\mathbf{C u}$ & Zn & $\mathbf{P b}$ & $\mathbf{F e}$ \\
\hline \multirow{8}{*}{130906} & 19667a_a & \multirow{8}{*}{18.41} & \multirow{8}{*}{ h: 3 , w: 2.8} & 80 & 17.6 & 2.4 & n.d. & n.d. & 0.18 \\
\hline & 19667a_b & & & 72 & 24.3 & 3.1 & n.d. & n.d. & 0.21 \\
\hline & 19667a_c & & & 76 & 21.3 & 2.5 & n.d. & n.d. & 0.25 \\
\hline & 19667a_d & & & 73 & 20.6 & 6.2 & n.d. & n.d. & 0.51 \\
\hline & 19667b_a & & & 79 & 18.6 & 2.5 & n.d. & n.d. & n.d. \\
\hline & 19667b_b & & & 75 & 21.9 & 2.5 & n.d. & n.d. & n.d. \\
\hline & 19667b_c & & & 77 & 20.5 & 2.4 & n.d. & n.d. & n.d. \\
\hline & 19667b_d & & & 76 & 21 & 2.6 & n.d. & n.d. & n.d. \\
\hline \multirow{2}{*}{130907} & 19668_a & \multirow{2}{*}{7} & \multirow{2}{*}{$1.5 \times 1.9 \times 1.3$} & 82 & 15.7 & 1.6 & n.d. & n.d. & n.d. \\
\hline & 19668 _c & & & 82 & 16 & 1.3 & n.d. & n.d. & n.d. \\
\hline \multirow{2}{*}{130887} & 19670_a & \multirow{2}{*}{16.22} & \multirow{2}{*}{$2.5 \times 2.1 \times 1.4$} & 86 & 12.1 & 1.4 & n.d. & n.d. & 0.2 \\
\hline & 19670_b & & & 84 & 13.8 & 1.8 & n.d. & n.d. & 0.45 \\
\hline \multirow{11}{*}{130908} & 19682_a & \multirow{11}{*}{11.43} & \multirow{11}{*}{$\begin{array}{c}\text { d: } 0.8, \text { dia.: } \\
2.8\end{array}$} & 82 & 15.3 & 2.5 & n.d. & n.d. & n.d. \\
\hline & 19682_b & & & 82 & 15.1 & 2.2 & n.d. & n.d. & n.d. \\
\hline & 19682 c & & & 82 & 15.1 & 2.2 & n.d. & n.d. & 0.11 \\
\hline & 19682_d & & & 80 & 16.4 & 3.2 & n.d. & n.d. & 0.33 \\
\hline & 19682_e & & & 80 & 16.1 & 2.8 & n.d. & n.d. & 1.30 \\
\hline & 19682 f & & & 56 & 10.2 & 7.7 & n.d. & n.d. & 25 \\
\hline & 19682_g & & & 75 & 17.4 & 7.5 & n.d. & n.d. & 0.12 \\
\hline & 19682 h & & & 81 & 16.6 & 2.6 & n.d. & n.d. & 0.17 \\
\hline & 19682_i & & & 81 & 16.2 & 2.4 & n.d. & n.d. & 0.15 \\
\hline & $19682 \mathrm{j}$ & & & 82 & 15.2 & 2.2 & n.d. & n.d. & n.d. \\
\hline & 19682_k & & & 82 & 14.8 & 2.5 & n.d. & n.d. & n.d. \\
\hline \multirow{6}{*}{130884} & 19683_a & \multirow{6}{*}{8.23} & \multirow{6}{*}{$\begin{array}{c}\mathrm{d}: 0.7, \mathrm{dia} .: \\
2.2\end{array}$} & 85 & 12.6 & 2 & n.d. & n.d. & 0.11 \\
\hline & 19683_b & & & 85 & 12.9 & 2.1 & n.d. & n.d. & 0.21 \\
\hline & 19683_c & & & 84 & 12.7 & 2.9 & n.d. & n.d. & 0.14 \\
\hline & 19683 d & & & 85 & 11.9 & 2.9 & n.d. & n.d. & 0.29 \\
\hline & 19683_e & & & 84 & 12.7 & 3 & n.d. & n.d. & 0.1 \\
\hline & 19683 f & & & 82 & 14.3 & 3.6 & n.d. & n.d. & 0.26 \\
\hline \multirow{3}{*}{130885} & 19685_a & \multirow{3}{*}{10.25} & \multirow{3}{*}{ dia.: 2.2} & 95 & 3.6 & 0.3 & n.d. & n.d. & 0.5 \\
\hline & 19685_b & & & 96 & 3.1 & 0.3 & n.d. & n.d. & 0.25 \\
\hline & 19685_c & & & 96 & 2.9 & 0.2 & n.d. & n.d. & 0.38 \\
\hline
\end{tabular}




\begin{tabular}{|c|c|c|c|c|c|c|c|c|c|}
\hline $\begin{array}{c}\text { Lab- } \\
\text { no. } \\
\text { (MA-) }\end{array}$ & Inv. no. & Weight (g) & Size (cm) & Au & Ag & $\mathrm{Cu}$ & Zn & $\mathbf{P b}$ & $\mathbf{F e}$ \\
\hline 130886 & 19699_a & 9.27 & $\begin{array}{c}\text { d: } 0.6, \text { dia.: } \\
1.9\end{array}$ & 71 & 24.1 & 4.6 & n.d. & n.d. & 0.13 \\
\hline \multirow{3}{*}{130888} & 19705_a & \multirow{3}{*}{7.35} & \multirow{3}{*}{$1.4 \times 1.4$} & 88 & 9.4 & 2.4 & n.d. & n.d. & 0.12 \\
\hline & 19705_b & & & 88 & 9.1 & 2.3 & n.d. & n.d. & 0.28 \\
\hline & 19705_c & & & 88 & 9.2 & 2.5 & n.d. & n.d. & 0.26 \\
\hline \multirow{3}{*}{130889} & 19714_a & \multirow{3}{*}{19.95} & \multirow{3}{*}{$\begin{array}{l}\text { h: } 2.8, \text { d: } 2.6 \text {, } \\
\text { dia.: } 3.1\end{array}$} & 81 & 17.3 & 1.8 & n.d. & n.d. & n.d. \\
\hline & 19714_b & & & 80 & 17.9 & 2.1 & n.d. & n.d. & 0.21 \\
\hline & 19714_c & & & 76 & 20.3 & 2.90 & n.d. & n.d. & 0.15 \\
\hline \multirow{3}{*}{130890} & 19715_a & \multirow{3}{*}{37.9} & \multirow{3}{*}{$2.3 \times 3.1 \times 1.1$} & 81 & 13.7 & 4.6 & n.d. & n.d. & 0.3 \\
\hline & 19715_b & & & 83 & 12.6 & 4 & n.d. & n.d. & 0.16 \\
\hline & 19715_c & & & 82 & 12.9 & 4.5 & n.d. & n.d. & 0.22 \\
\hline \multirow{2}{*}{130891} & 19721_a & \multirow{2}{*}{4.27} & \multirow{2}{*}{$\begin{array}{l}\text { h: } 2, \mathrm{~d}: 1.1 . \\
\quad \text { dia.: } 2\end{array}$} & 78 & 17.2 & 4.5 & n.d. & n.d. & 0.17 \\
\hline & 19721_b & & & 77 & 17.2 & 4.9 & n.d. & n.d. & 0.34 \\
\hline \multirow{2}{*}{130892} & 19722_a & \multirow{2}{*}{19.16} & \multirow{2}{*}{$\begin{array}{c}\text { h: } 2.1 \text {, dia.: } \\
2.6 \text { (bezel } \\
\text { dia.: } 1.7 \text { ) }\end{array}$} & 88 & 7.8 & 3.9 & n.d. & n.d. & n.d. \\
\hline & 19722_b & & & 89 & 8 & 3.2 & n.d. & n.d. & n.d. \\
\hline \multirow{4}{*}{130893} & 19724_a & \multirow{4}{*}{2.6} & \multirow{4}{*}{$\begin{array}{l}\text { h: } 1.7, \mathrm{~d}: 1, \\
\quad \text { dia.: } 1.8\end{array}$} & 59 & 33 & 6.8 & n.d. & n.d. & 0.7 \\
\hline & 19724_b & & & 59 & 33 & 7.3 & n.d. & n.d. & n.d. \\
\hline & 19724_c & & & 58 & 29.1 & 10.5 & n.d. & n.d. & 1.83 \\
\hline & 19724_d & & & 59 & 30.9 & 8.9 & n.d. & n.d. & 0.61 \\
\hline \multirow{4}{*}{130894} & 19732_a & \multirow{4}{*}{2.37} & \multirow{4}{*}{$\begin{array}{l}\text { h: } 1.5, \text { d: } 0.7, \\
\text { dia.: } 1.4\end{array}$} & 76 & 21.7 & 2.4 & n.d. & n.d. & n.d. \\
\hline & 19732_b & & & 78 & 19.2 & 2.8 & n.d. & n.d. & n.d. \\
\hline & 19732_c & & & 74 & 18.8 & 5.6 & n.d. & n.d. & 1.17 \\
\hline & 19732_d & & & 78 & 18.8 & 3.2 & n.d. & n.d. & n.d. \\
\hline \multirow{2}{*}{130895} & 19742_a & \multirow{2}{*}{6.14} & \multirow{2}{*}{ dia.: 2.1} & 95 & 3.8 & 0.6 & n.d. & n.d. & n.d. \\
\hline & 19742_b & & & 93 & 5.5 & 1 & n.d. & n.d. & n.d. \\
\hline \multirow{4}{*}{130896} & 19744_a & \multirow{4}{*}{25.94} & \multirow{4}{*}{ dia.: 2.5} & 93 & 5 & 1.2 & n.d. & n.d. & n.d. \\
\hline & 19744_b & & & 93 & 5 & 1.2 & n.d. & n.d. & 0.25 \\
\hline & 19744_c & & & 95 & 4.2 & 0.9 & n.d. & n.d. & n.d. \\
\hline & 19744_d & & & 94 & 5 & 1.3 & n.d. & n.d. & n.d. \\
\hline \multirow{2}{*}{130897} & 19746_a & \multirow{2}{*}{2.93} & h: 0.4 , dia.: & 89 & 9.4 & 0.9 & n.d. & n.d. & 0.32 \\
\hline & 19746_b & & & 88 & 10.3 & 1.1 & n.d. & n.d. & 0.17 \\
\hline
\end{tabular}




\begin{tabular}{|c|c|c|c|c|c|c|c|c|c|}
\hline $\begin{array}{c}\text { Lab- } \\
\text { no. } \\
\text { (MA-) }\end{array}$ & Inv. no. & Weight (g) & Size $(\mathrm{cm})$ & Au & Ag & $\mathrm{Cu}$ & Zn & $\mathbf{P b}$ & $\mathbf{F e}$ \\
\hline \multirow{5}{*}{130898} & 19749_a & \multirow{5}{*}{3.07} & \multirow{5}{*}{$\begin{array}{c}\text { h: } 0.8 \text {, dia.: } \\
1.9\end{array}$} & 77 & 19 & 3.5 & n.d. & n.d. & 0.14 \\
\hline & 19749_b & & & 80 & 18.4 & 0.8 & n.d. & n.d. & 0.25 \\
\hline & 19749_c & & & 81 & 18.3 & 0.7 & n.d. & n.d. & 0.26 \\
\hline & 19749_d & & & 81 & 17.8 & 0.9 & n.d. & n.d. & 0.16 \\
\hline & 19749_e & & & 81 & 18.1 & 0.9 & n.d. & n.d. & 0.2 \\
\hline \multirow{2}{*}{130899} & 19768_a & \multirow{2}{*}{5.08} & \multirow{2}{*}{ h: 1.7} & 81 & 17.2 & 1.4 & n.d. & n.d. & n.d. \\
\hline & 19768_b & & & 80 & 17.8 & 1.9 & n.d. & n.d. & n.d. \\
\hline \multirow{3}{*}{130900} & 19770_a & \multirow{3}{*}{4.61} & \multirow{3}{*}{ h: 1.8} & 84 & 14.4 & 1.3 & n.d. & n.d. & 0.29 \\
\hline & 19770_b & & & 84 & 13.3 & 1.1 & n.d. & n.d. & 1.37 \\
\hline & 19770_c & & & 86 & 12.8 & 1.2 & n.d. & n.d. & n.d. \\
\hline
\end{tabular}

Secondly, wire-wrapped rings are characterised by low concentrations of both silver and copper, which enables the winding of a flat, solid but malleable wire (Fig. 2-4). Their concentration does not exceed $10 \%$ silver and $1 \%$ copper. The wire-wrapped rings inlaid with a gemstone are made of a similar alloy of $12-17 \%$ silver and 3-4\% copper (Fig. 6-7). If we follow the dating of the wire-wrapped rings mentioned above, that the simple ones with hammered wire could be earlier than the more complex ones, no chronological sequence among the samples of this type is seen. This leads to the assumption that certain alloys seem typical of the manufacture of certain types of jewellery, and this was sustained over time. This result also confirms Riederer's observation (1999: 67) that the gold content in wires is relatively high, although he does not provide his data set for this assumption.

Thirdly, the analytical results reveal the presence of a silver-rich group, with a silver content of 38-59\%. Digital microscopy photographs show that the edges of the jewellery have a white colour, indicating that the pieces were gilded. This leads to falsified analytical data regarding the true alloy composition if nondestructive surface analyses are used. This group consists of cast ear ornaments and one ring (Fig. 11, 22-23, 26). Among them are not only tiny objects of simple design but also an elaborate figurative ear ornament and an auspicious ring. Gilding was, thus, not only a meant to use gold in an economic way, but also added aesthetic qualities. The use of depletion gilding is known at the early Cambodian site Prohear and seems to have been widely applied in jewellery and weapons in Java, at least since the early Classical Period, as recorded in the Kakawin Ramayana (Soewito Santoso 1980, II: 548: XXVI, 203; 559: XXI, 241; 569: XXII, 45; Schlosser et al. 2012; Bennett 2017: 71). 

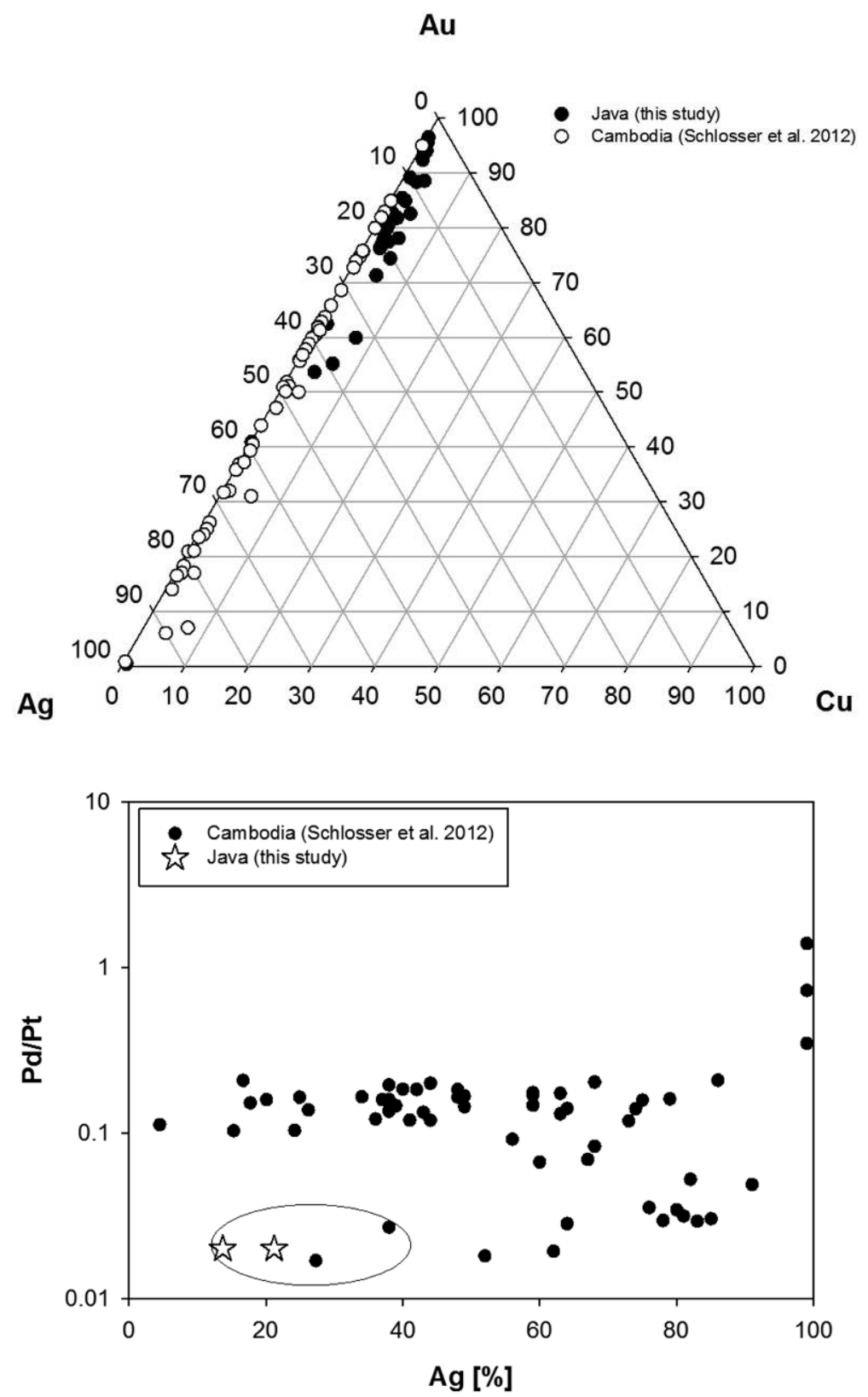

Fig. 31a-b - The ternary diagram shows the alloy composition and the scatterplot the silver and Palladium/ Platinum ratio $(\mathrm{Pd} / \mathrm{Pt})$ of jewellery from the Frankfurt Weltkulturen Museum and Cambodia: Au = gold, $\mathrm{Ag}=$ silver, $\mathrm{Cu}=$ copper $($ Schlosser et al. 2012; CEZA). 


\begin{tabular}{|c|c|c|c|}
\hline \multirow{15}{*}{ 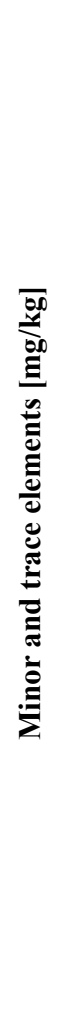 } & $\approx$ & $\stackrel{\circ}{i}$ & $\stackrel{\infty}{m}$ \\
\hline & 2 & 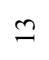 & ฝี่ \\
\hline & $\approx$ & 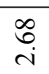 & $\begin{array}{l}\sigma \\
\dot{V}\end{array}$ \\
\hline & के & 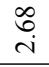 & $\infty$ \\
\hline & $\overline{5}$ & $\stackrel{\infty}{=}$ & $\stackrel{a}{a}$ \\
\hline & $\Xi$ & $\stackrel{+}{\vec{V}}$ & $\stackrel{\nabla}{\vec{V}}$ \\
\hline & ๗ั & $\begin{array}{l}\stackrel{n}{+} \\
\stackrel{f}{v}\end{array}$ & 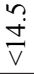 \\
\hline & $\pi$ & $\overrightarrow{\vec{v}}$ & $\begin{array}{l}\stackrel{0}{\mathbf{i}} \\
\text { in }\end{array}$ \\
\hline & $\Sigma$ & $\stackrel{?}{I}$ & 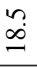 \\
\hline & $z$ & $\stackrel{\infty}{\infty}$ & 6 \\
\hline & 8 & $\stackrel{m}{\vec{v}}$ & $\stackrel{m}{\vec{v}}$ \\
\hline & $\Sigma$ & $\stackrel{8}{\exists}$ & $\frac{8}{m}$ \\
\hline & $\Xi$ & $\stackrel{?}{?}$ & $\begin{array}{l}0 \\
\stackrel{0}{2}\end{array}$ \\
\hline & 0 & 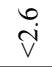 & $\begin{array}{l}0 \\
\stackrel{i}{v}\end{array}$ \\
\hline & $E$ & $\stackrel{t}{\stackrel{t}{I}}$ & $\stackrel{n}{\vec{v}}$ \\
\hline \multirow{7}{*}{ 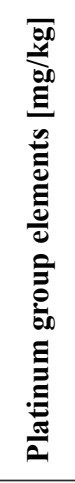 } & $\Xi \pm$ & $\stackrel{\tilde{O}}{\circ}$ & ô. \\
\hline & \pm & 学 & ల్ల \\
\hline & $=$ & gे & $\exists$ \\
\hline & 8 & $\begin{array}{l}0 \\
0 \\
0\end{array}$ & : \\
\hline & $\Xi$ & ชี & $\vec{r}$ \\
\hline & $\bar{\approx}$ & $\stackrel{\infty}{\stackrel{\sim}{\rightarrow}}$ & $\stackrel{\infty}{-}$ \\
\hline & $\bar{z}$ & $\stackrel{\ddot{v}}{\dot{v}}$ & $\stackrel{\vec{v}}{\dot{v}}$ \\
\hline \multirow{4}{*}{ 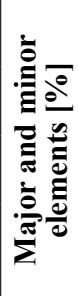 } & $\Xi$ & $\stackrel{0}{r}$ & $\stackrel{0}{+}$ \\
\hline & $\frac{80}{4}$ & $\frac{\mathcal{N}}{\vec{N}}$ & $\ddot{m}$ \\
\hline & $\Xi$ & $\therefore$ & $\tilde{\infty}$ \\
\hline & $\vec{g}$ & $\underset{⿱}{\stackrel{+}{S}}$ & $\frac{n}{a}$ \\
\hline
\end{tabular}


In addition to the determination of the major alloy components, the analyses of trace element patterns were carried out with LA-ICP-MS on two rings (Fig. 31b, Table 2). This technique allows the detection of even small amounts of impurities in the alloys, which might offer additional information about the raw materials, production processes and other information, such as the workshop or batch identification. Even though a data set of two objects is comparatively small, some important information is accessible. Both rings contain comparatively high amounts of trace elements. Taking the intentional addition of copper into account, it is not possible to ascertain whether the elements were added to the gold alloy by copper addition or belong to the gold ore. Copper generally contains traces of most of the elements analysed. One exception is the so-called platinum group elements, which are only present in a very low concentration in the copper. Hence, the presence of platinum group elements generally indicates the use of placer gold, as has already been discussed in papers dealing with the provenance of gold raw material (Chapman et al. 2006; Ehser et al. 2011; Jansen et al. 2016). Tin is also often used as indicator for placer gold, but the situation is more complex. The gold can be contaminated by not only tin while alloying with copper but also lode gold with cassiterite associations is known (in Europe, at least).

Recent studies yielded promising results using the platinum/palladium ratio to differentiate gold groups in prehistoric Southeast Asia (Schlosser et al. 2012; Calo et al. 2015). The platinum/palladium ratio of both rings from the Prillwitz collection analysed are very similar to the ratio reported by Ambra Calo (Calo et al. 2015) for gold found in Bali. The alloy composition of gold jewellery from early Cambodia and historic-period Java is plotted in Fig. $31 \mathrm{a}-\mathrm{b}$. This leads to the assumption that placer gold from different sources was used or recycled in Island Southeast Asia and Mainland Southeast Asia and thus constitute different groups.

\section{Conclusions}

The Prillwitz collection of jewellery in the Frankfurt Weltkulturen Museum provides a rich selection of rings and ear ornaments covering a wide span of time and various types, which allows new interpretations of motifs, chrono-typological markers and the assigning of historic terminology to specific jewellery types, in particular the eardrops (anting-anting), ear-studs (suwěng or pěpělik) and the propitiatory gift rings (simsim pasāda/prasāda). The quality of workmanship of the Prillwitz objects, including some unique types, is remarkable. Java's gold working advanced to a high level of technical knowledge and decorative innovations, so much so, that its goldsmithing, diverged greatly from other Asian regions in the late 1st millennium and new models of wire-wrapped rings, rings with auspicious motifs, eardrops, clips, fan-shaped types appeared. Jewellery was responsive to changing tastes and status differences are recognisable. Javanese goldsmiths used an array of 
motifs from other craftwork, in particular coins and intaglio which had already been disseminated during the 1st millennium from South Asia as models for their images on rings.

The chemical analyses of gold provide a good indicator of the state of metallurgical knowledge and alloying in ancient Java. The colour, hardness, strength or ductility of the metal were controlled by alloying gold with silver and copper. On the one hand, an alloy with a higher gold content was preferred for decorations, because it was easily moulded. On the other hand, rings made of gold sheet contain a relatively high amount of silver and copper because they had to be durable. Thus, certain alloys were deliberately chosen to obtain certain material properties. The analyses suggest that a complex gold-working industry existed, and craftsmen associated various types of alloys with different object groups and functions also taking aesthetic values, symbolic meaning and monetary value into account.

\section{Bibliography}

Agustijanto Indradjaja, Eka Putrina Taim and J. Arif. 2015. "Permukiman pra-Śriwijaya di kawasan situs Air Sugihan, Pantai Timur Sumatera." In Bambang Budi Utomo (ed.) Kehiduan Purba di Lahan Gambut. Jakarta: Kementerian Pendidikan dan Kebudayaan, 34-77.

Anonymous. 1941. "Oudheidkundige Dienst in Nederlandsch-Indië, Uitgegeven door het Koninklijk Bataviaasch Genootschap van Kunsten en Wetenschappen 1941." Oudheidkundig Verslag 1940. Batavia: Kon. Drukkerij De Unie.

Baldwin's.2011.The YashodaSingh CollectionofIndian Coins. Auction 71.London, 29September. https://www.sixbid.com/browse.html?auction=258\&category=3313 (consulted 6.4.2019).

Barnes, R. 2004. Ostindonesien im 20. Jahrhundert. Auf den Spuren der Sammlung Ernst Vatter. Frankfurt: Museum der Weltkulturen.

Barrett Jones, A. 1984. Early Tenth Century Java from the Inscriptions. A Study of Economic, Social and Administrative Conditions in the First Quarter of the Century. Dordrecht: Foris.

Bennett, A. T. N. 2009. "Gold in Early Southeast Asia.” ArchaeoSciences. Revue d'Archéométrie $33,99-107$.

Bennett, A. T. N. 2015. "Ancient Gold and Modern Fakes in Southeast Asia.” In R. Barnes, E. N. Stein and B. Diebold (eds.) Gold in Early Southeast Asia. New Haven: Yale Southeast Asia Studies, 183-236.

Bennett, A. 2017. The Ancient History of U Thong City of Gold. A Scientific Study of the Gold from U Thong. Bangkok: River Books.

Bosch, F. D. K. 1927. "Gouden vingerringen uit het Hindoe-Javaansche tijdperk.” Djawa 7 , 305-20.

Bosch, F. D. K. 1960. The Golden Germ. An Introduction to Indian Symbolism. 'S-Gravenhage: Mouton \& Co.

Bougas, W. A. 2007. "Gold Looted and Excavated from Late (1300 AD-1600 AD) Pre-Islamic Makassar Graves.” Archipel 73, 111-66.

Brenker, F. 2019. "Electron Microscopy Study of Red Stains on Javanese Gold.” In Golden Lotus Foundation (ed.) Java Gold. The Wealth of Rings. Milano: Golden Lotus Foundation, 210-8.

Brinkgreve, F., Hari Budiarti and A. Rozali. 2010. Kemegahan emas di Museum Nasional Indonesia. Golden Splendour in the National Museum of Indonesia. Jakarta: Museum Nasional Indonesia. 
Calo, A., Bagyo Prasetyo and P. Bellwood et al. 2015. "Sembiran and Pacung on the North Coast of Bali. A Strategic Crossroads for Early Trans-Asiatic Exchange." Antiquity 89/344, 378-96.

Capristano-Baker, F. 2011. "The Ayala Museum's Gold Collection.” In F. Capristano-Baker (ed.) Philippine Ancestral Gold. Manila: NUS Press, 21-136.

CEZA 2016. Bericht 13-016. Mannheim: CEZA (unpublished).

CEZA 14-072. Analytical Report MA-no. 145881. Mannheim: CEZA (unpublished and no date).

Chapman, R., R. C. Leake, R. Warner et al. 2006. "Microchemical Characterisation of Natural Gold and Artefact Gold as a Tool for Provenancing Prehistoric Gold Artefacts. A Case Study in Ireland." Applied Geochemistry - APPL GEOCHEM 21, 904-18.

Chin, E. 1994. "Classical Indonesian Gold Jewellery in a Private Collection." Arts of Asia 24/4, $55-60$.

Christie, J. W. 1993. Gold Rings Mentioned in Old Javanese and Old Balinese Language Inscriptions, typescript.

Christie, J. W.1998. "Javanese Markets and the Asian Sea Trade Boom of the Tenth to Thirteenth Centuries A.D." Journal of the Economic and Social History of the Orient 41/3, 344-81.

Christie, J. W. 2015. "Gold and Early Javanese Inscriptions." In R. Barnes, E. N. Stein and B. Diebold (eds.) Gold in Early Southeast Asia. New Haven: Yale Southeast Asia Studies, $75-88$.

Christie's Auction 2005. Indian Himalayan and Southeast Asian Art, Sale 2675. Amsterdam, 18 October.

Christie's Auction 2016. Art d'Asie, Sale 12689. Paris, 21-22 June.

Classical Numismatic Gallery 2014. Classical Numismatic Gallery. The Wardhaman Collection of Indian Coins, Part One. Auction 15. Mumbai, 2 February. Mumbai. https://classicalnumismaticgallery.com/document/auction/catalouge/AUC15.pdf (consulted 1.3.2019).

Creese, H. 2004. Women of the Kakawin World. Marriage and Sexuality in the Indic Courts of Java and Bali. London: Sharpe M. E.

Dalton, O. M. 1912. Franks Bequest Catalogue of the Finger Rings Early Christian, Byzantine, Teutonic, Mediaeval and Later. London: British Museum.

De Bock, E. 2014. Goud der Goden uit het oude Java. Rotterdam: Wereldmuseum.

Demandt, M. H. S. 2015. "Early Gold Ornaments of Southeast Asia. Production, Trade and Consumption." Asian Perspectives 54/2, 305-30.

Dizon, E. Z. 2015. Exit Conference for Kamhantik Archaeological Site (NM-IV-2011-F) Bgy. Buenavista, Mulanay, Quezon Province, Philippines July 2015 (manuscript).

Djafar, H. 2010. Kompleks persandian Batujaya. Rekonstruksi sejarah kebudayaan daerah pantai utara Jawa Barat. Jakarta/Bandung: EFEO, KITLV, PUSLIT et al.

Dupoizat, M.-F. and Naniek Harkantiningsih 2007. Catalogue of the Chinese Style Ceramics of Majapahit. Tentative Inventory. Paris: EFEO, Archipel, Cahiers d'Archipel 36.

Eggebrecht, A. and E. Eggebrecht. 1995. Versunkene Königreiche Indonesiens. Mainz: P. von Zabern.

Ehser, A., G. Borg and E. Pernicka. 2011. "Provenance of the Gold of the Early Bronze Age Nebra Sky Disk, Central Germany. Geochemical Characterization of Natural Gold from Cornwall." European Journal of Mineralogy 23/6, 895-910.

Eka Asih Putrina Taim. 2017. "Artefak emas Candi Buddha Sintong. Hubungan fungsi dan keletakannya." Naditira Widya 11/1 April, 17-30.

Ekowati Sundari. 2009. "Trade Ceramics from Sumatra in the Collection of the National Museum (Jakarta)." In F. Brinkgreve and Retno Sulistianingsih (eds.) Sumatra. Crossroads of Cultures. Leiden: KITLV, 97-106. 
Estrella, V. P. 2016. “Ancient Tagalog Goldworking Technology from Fray San Buenaventurs's Vocabulario de Lengua Tagala. Integrating Archaeological, Linguistic and Ethnohistoric Data." Hukay 20, 47-78.

Evans, I. H. N. 1932. "Excavations at Tanjong Rawa, Kuala Selinsing, Perak." Journal of the Federated Malay States Museum 15, 79-134.

Flecker, M. 2002. The Archaeological Excavation of the 10th Century Intan Wreck (BAR International Series 1047). Oxford: Archaeopress.

Friederich, R. H. T. 1856. Verklaring van inskriptien op gouden ringen van Java. Tijdschrift voor Indische Taal-, Land- en Volkenkunde 5, 471-83.

Friedrich, R. 2019. "Indirect Radiocarbon Dating of Gold Objects." In Golden Lotus Foundation (ed.) Java Gold. Hidden Treasures. Milano: Golden Lotus Foundation, 227-31.

G. K. 1984. "Das Linden-Museum Stuttgart im Jahr 1983 - Südasien-Abteilung." Tribus 33, $25-36$.

Gallop, Annabel Teh 2016. "The Early Use of Seals in the Malay World." Bulletin de l'École Française d'Extême-Orient 102, 125-63.

Geoffroy-Schneiter, B. and M. Crick. 2016. Bijoux d'Orients Lointains au Fil de l'Or au Fil de l'Eau. Geneva: Foundation Baur Musée des Arts d'Extrême-Orient.

Ghysels, E. 2000. A World of Rings. Africa, Asia, America. Milano: Skira.

Girard-Geslan, M. 1995. Les Ors d'Archipel Indonésien/Indonesian Gold. Treasures from the National Museum, Jakarta. Paris: Musée national des Arts asiatiques-Guimet.

Golden Lotus Foundation. 2018. Java Gold. The Wealth of Rings. Milano: Golden Lotus Foundation.

Golden Lotus Foundation. 2019. Java Gold. The Splendour of Jewellery. Milano: Golden Lotus Foundation.

Goris, R. 1927. "Storm-kind en geestes zoon.” Djawa 7, 110-3.

Griffiths, A. 2012. "The Epigraphical Collection of Museum Ranggawarsita in Semarang." Bijdragen tot de Taal-, Land-en Volkenkunde/Journal of the Humanities and Social Sciences of Southeast Asia and Oceania 168/4, 472-96.

Groeneveldt, W. P. and L. A. Brandes. 1887. Catalogus der Archeologische Verzameling van het Bataviaasch Genootschap van Kunsten en Wetenschappen. Batavia: Albrecht \& Co.

Guy, J. 2008. "Ornaments of Empowerment. The Kundala-Subang in Old Javanese Jewellery." Aziatische Kunst 38/4, 55-61.

Guy, J. 2011. "Gold in the Philippines. Form, Meaning, and Metamorphosis." In F. CapristanoBaker (ed.) Philippine Ancestral Gold. Manila: NUS Press, 163-90.

Habsburg-Feldman SA. 1990. Gold - Important Ancient and Ethnic Jewellery and Work of Art in Precious Metal to be offered for Sale by Auction at the Hotel des Bergues, Geneva. Geneva: Habsburg-Feldman SA.

Hall, K. R. 2000. "Personal Status and Ritualized Exchange in Majapahit Java." Archipel 59, 51-96.

Harrison, T. 1969. "The Golden Hoard of Limbang.” Brunei Museum Journal 1/1, 57-71.

Hinzler, H. I. R. 1999. "Dharmakancana, the Magic Spell for Making Gold. Gold and Jewellery in Hindu-Buddhist Java from the 10th to the 15th Century." In W. H. Kal (ed.) Precious Metals in Early South East Asia. Proceedings of the Second Seminar on Gold Studies. Amsterdam: Royal Tropical Institute, 27-38.

Jansen, M., S. Aulbach, A. Hauptmann et al. R. 2016. "Platinum Group Placer Minerals in Ancient Gold Artifacts - Geochemistry and Osmium Isotopes of Inclusions in Early Bronze Age Gold from Ur/Mesopotamia." Journal of Archaeological Science 68, 12-23.

Jasper, J. E. and Mas Pirngadie. 1927. De inlandsche Kunstnijverheid in Nederlandsch Indië, Vol. IV: De Goud- en Zilversmeedkunst. 'S-Gravenhage: Mouton \& Co.

Jessup, H. I. 1990. Court Arts of Indonesia. New York: Asia Society Galleries. 
Juynboll, H. H. 1909. Katalog des Ethnographischen Reichsmuseums, Vol. V: Javanische Altertümer. Leiden: Brill.

W. H. Kal (ed.) 1999. Precious Metals in Early South East Asia. Proceedings of the Second Seminar on Gold Studies. Amsterdam: Royal Tropical Institute.

Karow, O. 1987. Terrrakottakunst des Reiches Majapahit in Ostjava. Katalog zur Ausstellung. Das Sparschwein unter dem Reisfeld. Frankfurt: Museum für Völkerkunde Frankfurt am Main.

Karunaratne, T. B. 1971. "Astamangala. The Eight Auspicious Symbols.” Journal of the Ceylon Branch of the Royal Asiatic Society (Colombo), New Series XV, 48-70 and pls. I-V.

Kieven, L. 2013. Following the Cap-Figure in Majapahit Temple Reliefs. A New Look at the Religious Function of East Javanese Temples, Fourteenth and Fifteenth Centuries. Leiden: Brill.

Kinney, A. R. with M. Klokke and L. Kieven. 2003. Worshipping Siva and Buddha. The Temple Art of East Java. Honolulu: University of Hawai'i Press.

Kumar, A. 2015. "Labyrinths in Rock Art. Morphology and Meaning with Special Reference to India." Journal of Multidisciplinary Studies in Archaeology 3, 84-104.

Kusen. 1983. "Catatan singkat mengenai cincin bertulisan "sramāna"." Berkala Arkeologi IV/2, 9-15.

Levin, C. 2003. "Glittering Emblems. Design Schema and Meaning of Classical Javanese Gold." In A. Karlstöm and A. Källén (eds.) Fishbones and Glittering Emblems. Southeast Asian Archaeology 2002. Stockholm: Museum of Far Eastern Antiquities, 371-80.

Levin, C. 2005. "Links of Gold. Hiranyasraj. Classical Javanese Gold and the South Idian Jewellery Tradition." In L. Mattet (ed.) Icons in Gold. Jewelry of India from the Collection of the Musée Barbier-Mueller. Paris and Geneva: Musée Barbier-Mueller and Somogy éditions d'art, 74-95.

Liebner, H. H. 2014. The Siren of Cirebon. A Tenth-Century Trading Vessel Lost in the Java Sea. PhD thesis. 2 vol. The University of Leeds. https://www.academia.edu/6900344/ Nanhan_Cirebon_Wreck_thesis_text_corrected_final (consulted 13.2.2018).

Lockhoff, N. 2018. "Analytical Methods of Testing Gold.” In Golden Lotus Foundation (ed.) Java Gold. The Wealth of Rings. Milano: Golden Lotus Foundation, 250-4.

Lockhoff, N. and E. Pernicka. 2014. "Archaeometallurgical Investigations of Early Bronze Age Gold Artefacts from Central Germany Including Gold from the Nebra Hoard.” In H. Meller, R. Risch and E. Pernicka (eds.) Metalle der Macht - Frühes Gold und Silber. Tagungen des Landesmuseums für Vorgeschichte Halle, Vol. 11/1. Halle: Salzland Druck, 223-45.

Lunsingh Scheurleer, P. 1994. "Meandering Clouds for Earrings. The Stylistic Approach to Dating." In W. H. Kal (ed.) Old Javanese Gold (4th-15th Century). An Archaeometrical Approach. Amsterdam: Royal Tropical Institute, 18-29.

Lunsingh Scheurleer, P. 2010. "The Archaeological Gold Collection. Javanese Treasures from Javanese Soil.” In F. Brinkgreve, Hari Budiarti and A. Rozali (eds.) Kemegahan emas di Museum Nasional Indonesia. Golden Splendour in the National Museum of Indonesia. Jakarta: Museum Nasional Indonesia, 24-33.

Lunsingh Scheurleer, P. 2012. Goud uit Java. The Hague: Gemeentemuseum and W Books.

Lunsingh Scheurleer, P. 2013. “Old Javanese Jewellery.” In F. Brinkgreve and D. J. StuartFox (eds.) Living with the Frits Liefkes Collection. Indonesian Art. Leiden: Rijksmuseum Volkenkunde and National Museum of Ethnology Amsterdam: KIT Publishers, 124-5.

Maas, A. 1924. "Sternkunde und Sterndeuterei im Malaiischen Archipel." Tijdschrift voor Indische Taal-, Land- en Volkenkunde 64, 1-172, 347-460.

Machi Suhadi. 1999. "Old Javanese Inscribed Rings and Inscriptions on Gold." In W. H. Kal (ed.) Precious Metals in Early South East Asia. Proceedings of the Second Seminar on Gold Studies. Amsterdam: Royal Tropical Institute, 92-6.

Mahlo, D. 2012. The Early Coins of Myanmar (Burma). Messengers from the Past. Messengers from the Past. Pyu, Mon, and Candras of Arakan (first Millennium AD). Bangkok: White Lotus. 
Malleret, L. 1962. L'archaéologie du Delta du Mékong. Vol. 3: La culture du Fou-Nan. Publications de l'École française d'Extrême-Orient 43. Paris: École française d'ExtrêmeOrient.

Manning, A., E. E. McKinnon and F. E. Treloar. 1980. "Analysis of Gold Artefacts from Kota Cina Site near Medan, Sumatra." Journal of the Malaysian Branch of the Royal Asiatic Society 53/2, 102-16.

Marshall, J. 1975. Taxila. An Illustrated Account of Archaeological Excavations Carried out at Taxila under the Orders of the Government of India between the Years 1913 and 1934, Vol. III. Cambridge: University Press.

Marzio, F. 2011. The Glassell Collections of The Museum of Fine Arts, Houston. Masterworks of Pre-Columbian, Indonesian and African Gold. New Haven and London: Yale University.

Middleton, S. E. H. 2005. Intaglios, Cameos, Rings and Related Objects from Burma and Java. The White Collection and a Further Small Private Collection (BAR International Series 1405). Oxford: Archeopress.

Miksic, J. 1988. Small Finds. Ancient Javanese Gold. Singapore: National Museum.

Miksic, J. 1990. Old Javanese Gold. Singapore: Ideation.

Miksic, J. 2011a. Old Javanese Gold. The Hunter Thompson Collection at the Yale University Art Gallery ( $2^{\text {nd }}$ ed.). New Haven, CT: Yale University Press.

Miksic, J. N. 2013. Singapore \& the Silk Road of the Sea 1300 1800. Singapore: NUS Press.

National Museum of Indonesia. 2013. Jewelery. The Collections of the National Museum of Indonesia. Jakarta: BAB Publishing.

Miksic, J. N. and Endang Sri Hardiati Soekatno (ed.). 1995. The Legacy of Majapahit. Singapore: National Heritage Board.

Pernicka, E. 2018. "Scientific Analyses of Javanese Gold.” In Golden Lotus Foundation (ed.) Java Gold. The Wealth of Rings. Milano: Golden Lotus Foundation, 29-33.

Polak, J. 1980. “Indojavanischer Schmuck.” In Linden-Museum Stuttgart (ed.) Java und Bali. Buddhas Götter Helden Dämonen. Mainz: P. von Zabern, 123-33.

Przyluski, J. 1925. "La princesse à l'odeur de poisson et la nagi dans les traditions de l'Asie Orientale.” Études Asiatiques publiées à l'occasion du vingt-cinquième anniversaire de l'École Française d'Extrême Orient. 2 vol. Paris: École Française d'Extrême Orient, 265-84.

Queensland Art Gallery. 1999. Indonesian Gold. Treasures from the National Museum, Jakarta. South Brisbane: Queensland Art Gallery.

Ramli, Z., N. H. Shuhaimi, N. H., Rahman et al. 2016. "Archaeological Discoveries of 200 BC Coastal Settlement in Pulau Kelumpang, Matang, Perak." The Social Sciences 11/13, 3264-70.

Rani, S. 1957. "Ślokāntara." An Old Javanese Didactic Text. New Delhi: International Academy of Indian Culture.

Reinecke, A. 2015. "Ancient Gold and Silver Jewelry and the Beginnings of Gold Working in Mainland Southeast Asia." In R. Barnes, E. N. Stein and B. Diebold (eds.) Gold in Early Southeast Asia. New Haven: Yale Southeast Asia Studies, 126-66.

Reinecke, A. and Nguyen Thi Thanh Luyen. 2009. "Recent Discoveries in Vietnam. Gold Masks and Other Precious Items." Arts of Asia 39/5 (Sept.-Oct.), 58-67.

Richter, A. 2010. The Jewelry of Southeast Asia. London: Thames and Hudson.

Riederer, J. 1994. "The Goldsmith's Techniques. The Technological Analysis of Early Gold Objects from Java." In W. H. Kal (ed.) Old Javanese Gold (4th-15th century). An Archaeometrical Approach. Amsterdam KIT and Tropenmuseum, 46-57.

Riederer, J. 1999. "Analysis of Gold Objects." In W. H. Kal (ed.) Precious Metals in Early South East Asia. Proceedings of the Second Seminar on Gold Studies. Amsterdam: Royal Tropical Institute, 65-8.

Rispoli, F. 2000. L'Oro degli Archipelaghi, Gioielli dall'Indonesia e dale Filippine. Rome: Museo Nazionale d'Arte Orientale. 
Robson, S. O. 1971. Wanban Wideya. A Javanese Panji Romance. 'S-Gravenhage: N.V. de Nederlandsche Boek.

Robson, S. O. 1981. "Notes on the Cultural Background of the kidung Literature." In N. Philipps and Khaidir Anwar (eds.) Papers on Indonesian Languages and Literatures. London and Paris: SOAS, 105-20.

Sahai, B. 1998. "Fish in Indian Art." In C. P. Sinha, Kameshwar Prasad, Jagdishwar Pandey et al. (eds.) Facets of Indian Culture. Gustav Roth Felicitation Volume, Published on the Occasion of his 82nd Birthday. Patna: Bihar Puravid Parishad, 244-51.

Schlosser, S., A. Reinecke, R. Schwab et al. 2012. "Early Cambodian Gold and Silver from Prohear. Composition, Trace Elements and Gilding." Journal of Archaeological Science $39,2877-87$.

Schorer, B., V. Leusch and R. Schwab. 2018. "New Insights into Hallstatt Gold from Southwest Germany. Technological Aspects and Material Analyses." In R. Schwab, P. Y. Milcent, B. Armbruster et al. (eds.) Early Iron Age Gold in Celtic Europe. Proceedings of the International Congress held in Toulouse, France, 11-14 March 2015. Rahden: Marie Leidorf, 181-229.

Shirley Day Ltd. 1992. The Ancient Art of South East Asia. London: Shirley Day Ltd.

Shirley Day Ltd. 1993. The Ancient Art of South East Asia. Part 2. London: Hillingdon.

Shuhaimi, N. H. 1991. "Recent Research at Kuala Selinsing, Perak." Bulletin of the IndoPacific Prehistory Association 11, 141-52.

Soekatno, TW. 1982. "Sepasang Arca Emas dari Dua Seplawan Purworejo, Jawa Tengah." In Proyek Penelitian Purbakala (ed.) Pertemuan Ilmiah Arkeologi ke II, Jakarta, 2-29 Pebruari 1980. Jakarta: Proyek Penelitian Purbakala, 207-25.

Soewito Santoso. 1980. Indonesian Rāmāyaņa. 3 vol. New Delhi: Sharada Rani, Hauzkhas Enclave.

Sri Soejatmi Satari. 1999. "Modesty Plates in the Hindu Buddhist Period. Functional Use or More Ornament?” In W. H. Kal (ed.) Precious Metals in Early South East Asia. Proceedings of the Second Seminar on Gold Studies. Amsterdam: Royal Tropical Institute, 85-91.

Sri Wahyuni. 2010. "After Burglary, Sonobudoyo Museum tightens Security." The Jakarta Post 19.8.2010, 9.

Stark, P. 1992. Gold \& Silver Auction. Part I Ancient to Tribal. New York: Taisei Gallery.

Sternberg, P. 1995. Gold of Asia. Ancient to Tribal Classical. Auction 30. Zürich, 9 November 1995.

Stutterheim, W. F. 1937. "De Oudheden-Collectie van Z. H. Mangkoenagoro VII te Soerakarta." Djawa 17/1-2, 1-112.

Swan, R. and D. Scott. 1986. "Gold Work from Kota Cina. A Technical Study.” In I. Glover and E. Glover (eds.) Southeast Asian Archaeology, 1986. Proceedings of the First Conference of the Association of Southeast Asian Archaeologists in Western Europe, Institute of Archaeology, University College London, 8th-10th September, 1986. Oxford: BAR, 275-86.

Tan, T. 2015. Ancient Jewellery of Myanmar. From Prehistory to Pyu Period. Yangon, Myanmar: Mudon Sar Pae Publishing House.

Timbul Haryono. 2012. "A Sketch of Metal-working in Early Java." In Edi Sedyawati and I Wayan Ardika (eds.) Recent Studies in Indonesian Archaeology. Delhi: Publishing Corporation, $165-73$.

Tjoa-Bonatz, M. L. 2017a. "Ein unentdeckter Goldschatz in der Mainmetropole." Indonesienmagazin, 26-7.

Tjoa-Bonatz, M. L. 2017b. Goldsammlung aus Java. Ein Goldschatz in der Mainmetropole. http://www.indonesienmagazin.de/index.php/wissen/224-ein-goldschatz-in-dermainmetropole (consulted 13.02.2018).

Tjoa-Bonatz, M. L. 2018. Schmuck und Gold als Austausch- und Zahlungsmittel im klassischen Java, Indonesien. Der Primitivgeldsammler 39/2, 54-60. 
Tokyo National Museum 1997. Treasures of Ancient Indonesian Kingdoms. Tokyo: Tokyo National Museum.

Veltman, T. J. 1904. "Note betreffende de Atjèhsche Goud- en Zilversmeedkunst." Tijdschrift voor Indische Taal-, Land- en Voolkenkunde 47, 341-77.

Villareal, F. W. L. 1995. Philippine Prehistoric Gold Bead Catalogue. Manila: GEBA.

Villegas, R. N. 2004. Ginto. History wrought in Gold. Manila: Bangko Sentral ng Pilipinas.

Wahyono Martowikrido. 1994. "The Gold of Wonoboyo. Preliminary Notes." In W. H. Kal (ed.) Old Javanese Gold (4th-15 th century). An Archaeometrical Approach. Amsterdam KIT and Tropenmuseum, 30-45.

Wenzel, M. 1993. Ornament and Amulet. Rings of the Islamic Lands. The Nasser D. Khalili Collection of Islamic Art, Vol. XVI. London: Oxford University Press.

Westerkamp, P. 1995. "Jewellery in Indonesia. Symbols of Cosmic Worlds." In J. Walgrave and H. Dedecker (eds.) Sieraad Symbool Signaal. Antwerp: Koningin Fabiolazaal, 51-6.

Williams, C. A. S. 1976. Outlines of Chinese Symbolism \& Art Motives ( $3^{\text {rd }}$ revised ed.). New York: Dover.

Yeow L. 2007. The Divine within Art and Living Culture of India South Asia. Singapore: Asian Civilizations Museum.

Zoetmulder, P. J. 1974. Kalangwan. A Survey of Old Javanese Literature. The Hague: Martinus Nijhoff.

Zoetmulder, P. J. 1982. Old Javanese-English Dictionary. 'S-Gravenhage: M. Nijhoff. http:// sealang.net/ojed/ (consulted 5.4.2017). 